Article

\title{
Gestational Diabetes Mellitus Treatment Schemes Modify Maternal Plasma Cholesterol Levels Dependent to Women's Weight: Possible Impact on Feto-Placental Vascular Function
}

\author{
Susana Contreras-Duarte ${ }^{1, *}$, Lorena Carvajal ${ }^{1}$, María Jesús Garchitorena ${ }^{1}$, Mario Subiabre ${ }^{1}$, \\ Bárbara Fuenzalida ${ }^{1}$, Claudette Cantin ${ }^{1}$, Marcelo Farías ${ }^{1}$ and Andrea Leiva ${ }^{1,2, *}$ \\ 1 Department of Obstetrics, School of Medicine, Pontificia Universidad Católica de Chile, Santiago 8330024, \\ Chile; lpcarvaja@uc.cl (L.C.); mjgarchitorena@uc.cl (M.J.G.); mesubiabre@uc.cl (M.S.); \\ bmfuenzalida@uc.cl (B.F.); clcantin@uc.cl (C.C.); mfarias@med.puc.cl (M.F.) \\ 2 School of Medical Technology, Health Sciences Faculty, Universidad San Sebastian, Santiago 8330024, Chile \\ * Correspondence: secontre@uc.cl (S.C.-D.); aaleiva@uc.cl (A.L.); Tel.: +562-23548116
}

Received: 30 December 2019; Accepted: 11 February 2020; Published: 17 February 2020

\begin{abstract}
Gestational diabetes mellitus (GDM) associates with fetal endothelial dysfunction (ED), which occurs independently of adequate glycemic control. Scarce information exists about the impact of different GDM therapeutic schemes on maternal dyslipidemia and obesity and their contribution to the development of fetal-ED. The aim of this study was to evaluate the effect of GDM-treatments on lipid levels in nonobese $(\mathrm{N})$ and obese $(\mathrm{O})$ pregnant women and the effect of maternal cholesterol levels in GDM-associated ED in the umbilical vein (UV). O-GDM women treated with diet showed decreased total cholesterol (TC) and low-density lipoproteins (LDL) levels with respect to N-GDM ones. Moreover, O-GDM women treated with diet in addition to insulin showed higher TC and LDL levels than N-GDM women. The maximum relaxation to calcitonin gene-related peptide of the UV rings was lower in the N-GDM group compared to the N one, and increased maternal levels of TC were associated with even lower dilation in the N-GDM group. We conclude that GDM-treatments modulate the TC and LDL levels depending on maternal weight. Additionally, increased TC levels worsen the GDM-associated ED of UV rings. This study suggests that it could be relevant to consider a specific GDM-treatment according to weight in order to prevent fetal-ED, as well as to consider the possible effects of maternal lipids during pregnancy.
\end{abstract}

Keywords: GDM; cholesterol; glycemia; GDM treatment; vascular function

\section{Introduction}

Gestational diabetes mellitus (GDM) is a pathology characterized by any degree of glucose intolerance first recognized during pregnancy [1,2]. GDM prevalence varies between $1 \%-25 \%$ according to the studied ethnic group and the diagnosis criteria followed $[1,3]$. The risk of developing GDM increases as maternal weight increases; therefore, the odds ratio for GDM is higher in obese women [4-7]. In addition, this pregnancy disease, with or without obesity, has consequences for the fetus, including pathological alterations of the feto-placental vasculature [8-11]. Additionally, GDM is associated with a higher risk of developing macrosomia $[1,3,12]$, which is associated with an increased risk of developing cardiovascular disease (CVD) during childhood and adulthood. Furthermore, the maternal complications of GDM include an increased risk of developing endothelial dysfunction [13,14], supraphysiologic dyslipidemia [15,16], long-term type 2 diabetes mellitus (T2DM) postpartum $[12,17,18]$ and CVD $[19,20]$, among others. Therefore, an optimal management strategy 
of GDM is suggested to prevent or diminish the associated risks for both the mother and the newborn. Currently, the first-line treatment of GDM used for the optimal control of glycemia is dietary carbohydrate restriction [1,18]. If dietary treatment does not properly control glycemia, metformin and/or insulin therapy are added to the GDM management strategy [1,21]. Nevertheless, it has been described that, even after glycemic control is achieved by diet or insulin, feto-placental endothelial dysfunction is still observed in women with GDM [11,22]. This result suggests that there may be additional mechanisms other than glucose levels involved in the regulation of placental endothelial dysfunction [22].

Remarkably, feto-placental endothelial dysfunction has also been detected in pregnancies with supraphysiological increases in cholesterol levels [23-25], a condition highly prevalent in pregnant women with GDM. Interestingly, the placental vasculature lacks innervation [26] and therefore the classical vasodilators (acetylcholine and sodium nitroprusside) used in aortic or mesenteric vessels are not efficient in the placental bed. Even when calcitonin gene-related peptide (CGRP) is an unusual vasodilator in classical experiments in aortic or mesenteric vasculature, in the human placental vessels, including the umbilical vessels (veins and arteries), it is used as an endothelium-dependent relaxing agent $[23,27]$.

Currently, the treatments for GDM are mainly focused on maintaining physiological glucose levels and an optimal maternal weight $[1,28]$. However, the control of other factors, such as dyslipidemia, is not considered like in patients with T2DM [29,30], and therefore is not considered as part of the GDM management strategy. Furthermore, information concerning the impact of GDM treatments on the lipid profile of mothers with GDM is indirect and controversial [31-39]. Therefore, the aim of this study is to determine the effect of GDM treatments on the maternal lipid profile and the impact of these changes in the GDM-associated feto-placental vascular function.

\section{Materials and Methods}

\subsection{Study Subjects}

A group of 4731 pregnant women from Hospital Clínico UC-Christus (Chile) were recruited for this retrospective and cross-sectional study. Among them, 365 women developed GDM. Lipid profiles were determined in a sample of 117 patients with GDM and 41 control (C) pregnant women.

The $C$ and GDM women who had their lipid profiles determined during pregnancy were separated into groups, according to which pregnancy trimester samples were obtained and to body mass index (BMI). The groups were categorized as C $(n=41)$, nonobese GDM (N-GDM, $n=69)$ or obese GDM (O-GDM, $n=48$ ), and the women were separated into first trimester (T1, from 0 to 14 weeks of gestation), second trimester (T2, from 14 to 28 weeks of gestation) and third trimester (T3, from 28 to 40 weeks of gestation) groups. Women with a pregestational BMI $\left(\mathrm{kg} / \mathrm{m}^{2}\right)<30$ were considered nonobese, while those with a BMI $\geq 30$ were considered obese [28,40]. Umbilical cord and blood samples were collected from the women at term. Maternal age, height and fasting glycemia values were obtained in T1. In T2 insulin levels, the glycosylated hemoglobin ( $\mathrm{HbA} 1 \mathrm{c})$ and homeostasis model assessment for insulin resistance (HOMA-IR) were determined. Oral glucose tolerance tests (OGTT) were also performed. Weight, body mass index and blood pressure data were obtained in all trimesters. Neonatal sex, gestational age, height, weight and ponderal index were determined and measured at birth. Authorized medical personnel from the patient clinical record system at the Hospital Clínico UC-Christus obtained all of the data. The reference values were determined according to the Institute of Medicine (IOM) (weight) [28], The American College of Obstetricians and Gynecologists (ACOG) (blood pressure) [41], American diabetes association (ADA) (basal glycemia, OGTT, HbA1c) [1,42,43], and the studies by Schnell et al. (insulin) [44] and Buccini and Wallace et al. (HOMA) [45-48].

For the analysis of the studied group, women with hyperthyroidism, fetal malformation, preeclampsia, hypertensive chronic syndrome, intrauterine growth restriction, insulin resistance, diabetes mellitus type 2 and/or abnormal umbilical artery Doppler results, multiple pregnancies, 
maternal tobacco use, alcohol or drug consumption, intrauterine infection or other medical obstetrical complications were excluded. Additionally, women who did not give informed consent or were under 18 years old were also excluded.

Our research was performed according to the Declaration of Helsinki and obtained approval from the Ethics Committee of the School of Medicine at Pontificia Universidad Católica de Chile (170803008), together with approval from the informed consent obtained from each participant.

\subsection{GDM Diagnosis and Treatment}

GDM was diagnosed with the NICE criteria [49] between the 24th and 28th week of gestation with one of two values over the following cut-off points: fasting glycemia $\geq 100 \mathrm{mg} / \mathrm{dL}(5.6 \mathrm{mmol} / \mathrm{L})$ or $\geq 140 \mathrm{mg} / \mathrm{dL}(7.8 \mathrm{mmol} / \mathrm{L})$ at two hours after a $75 \mathrm{~g}$ glucose load [49,50].

The first treatment strategy for GDM was a reduced carbohydrate diet $(1500 \mathrm{kcal} / \mathrm{day}$ and a maximum of $200 \mathrm{~g} / \mathrm{day}$ of carbohydrates). If diet restriction was not enough to achieve proper glycemic control by self-monitoring, metformin (0.5-1.7 g/day) and/or insulin therapy were started [21,51]. The initial doses of insulin consisted of two injections before breakfast and bedtime of neutral protamine Hagedorn human insulin and/or injections of rapid-acting insulin before meals as needed. The recommended dosages of metformin and insulin were adjusted according to the patient's needs, from $500 \mathrm{mg}$ to $2000 \mathrm{mg}$ per day. Optimal metabolic control during GDM management was monitored and recorded by each patient (delivered to the clinical staff) using serial capillary measurements of glycemia before and after meals, and glycated hemoglobin was measured in the clinical laboratory. The clinical targets of glycemic control were capillary glycemia values of $60-90 \mathrm{mg} / \mathrm{dL}$ before breakfast, 60-105 mg/dL before other meals, $<140 \mathrm{mg} / \mathrm{dL}$ one hour after meals, $<120 \mathrm{mg} / \mathrm{dL}$ two hours after meals and 60-99 mg/dL during the night, and $\mathrm{HbA1c}<6.0 \%$ [50]. Plasma glucose levels were measured at T3 to confirm the achievement of glycemic control by the different treatment options.

\subsection{Determination of Lipid Profiles}

Maternal blood concentrations of total cholesterol (TC), low density lipoprotein (LDL), high density lipoprotein (HDL), very low density lipoprotein (VLDL) and triglycerides (TG) were determined in maternal brachial venous blood after 8 hours of fasting during T1 and T2 and no fasting during T3. TC, HDL and TG were determined via standard enzymatic-colorimetric assays (Cobas Integra Cholesterol (CHOLL), Cobas Integra HDL cholesterol (HDL- C), and Cobas Integra Triglycerides (TRICL) kits, Roche Diagnostic Corporation, Indianapolis, IN, USA) in a Cobas 8000 modular analyzer series (Roche Diagnostic Corporation) at the Clinical Laboratory of the Hospital Clínico UC-Christus. LDL and VLDL cholesterol were calculated from TC; HDL and TG concentrations, by applying Friedewald's equation, as described elsewhere [23].

\subsection{High Cholesterol Cut-Off Value}

For umbilical vein reactivity assays, normal total cholesterol (NTC) or high total cholesterol (HTC) levels were defined as being over a cut-off point of $280 \mathrm{mg} / \mathrm{dL}$ at the term of pregnancy, based on the literature $[23,24,27,52-56]$.

\subsection{Umbilical Vein Reactivity}

Ring segments of 2-4 mm in length were dissected from human umbilical veins in phosphate buffered solution (PBS) $(130 \mathrm{mmol} / \mathrm{L} \mathrm{NaCl}, 2.7 \mathrm{mmol} / \mathrm{L} \mathrm{KCl}, 0.8 \mathrm{mmol} / \mathrm{L} \mathrm{Na} 2 \mathrm{HPO} 4,1.4 \mathrm{mmol} / \mathrm{L}$ $\left.\mathrm{KH} 2 \mathrm{PO} 4, \mathrm{pH} 7.4,4{ }^{\circ} \mathrm{C}\right)$. Vein rings were mounted in a myograph (610M Multiwire Myograph System, Danish Myo Technology A/S, Denmark) for isometric force measurements in a Krebs physiological solution (118.5 mmol/L NaCl, $4.7 \mathrm{mmol} / \mathrm{L} \mathrm{KCl}, 25 \mathrm{mmol} / \mathrm{L} \mathrm{NaHCO} 3,1.2 \mathrm{mmol} / \mathrm{L} \mathrm{MgSO} 4,1.2 \mathrm{mmol} / \mathrm{L}$ $\mathrm{KH} 2 \mathrm{PO} 4,2.5 \mathrm{mmol} / \mathrm{L} \mathrm{CaCl} 2,5.5 \mathrm{mmol} / \mathrm{L}$ D-glucose, $37^{\circ} \mathrm{C}, \mathrm{pH} 7.4$ ) bubbled with a mixture of $95 \%$ $\mathrm{O}_{2} / 5 \% \mathrm{CO}_{2}$. The optimal diameter for each vessel was determined by the maximal active response to $65 \mathrm{mmol} / \mathrm{L} \mathrm{KCl} \mathrm{[25].} \mathrm{UV} \mathrm{optimal} \mathrm{diameters} \mathrm{for} \mathrm{N}$ and GDM women were comparable between 
groups ( $4.82 \pm 0.25$ and $5.54 \pm 0.41$, respectively). All the experiments were performed in vessels at the optimal diameter.

Endothelium-dependent relaxation was evaluated as the response to calcitonin gene-related peptide (CGRP, 0.001-1000 nmol/L, 5 minutes) (Sigma-Aldrich) in $\mathrm{KCl}$ - preconstricted vessels $(32.5 \mathrm{mmol} / \mathrm{L}$ because at this concentration the vasodilatory response of the umbilical vein is detectable and subjected to modulation) in the absence or presence of $100 \mu \mathrm{mol} / \mathrm{L}$ NG-nitro-L-arginine methyl ester (L-NAME) and a nitric oxide synthase (NOS) inhibitor (20 minutes). Changes in isometric tension were recorded using the software LabChart (LabChart 7 for Windows, ADInstruments, Australia) coupled to a PowerLab data acquisition system (PowerLab 8/30 Data Acquisition System, ADInstruments, Australia). Maximal relaxation $\left(\mathrm{R}_{\max }\right)$ of the vessels was determined as the percentage of relaxation caused by CGRP compared to the maximal contraction. The data were graphed as the difference between the response to CGRP in the absence of L-NAME and the response to CGRP in the presence of the NOS inhibitor (NOS-dependent relative response). However supplementary Figure S1 shows maximal relaxation with or without L-NAME in controls and GDM groups. The concentration of the drug required the production of $50 \%$ of the maximum relaxation $\left(\mathrm{EC}_{50}\right)$ and was calculated and tabulated.

\subsection{Data Analysis}

Clinical data are presented as the mean \pm S.D. For vascular reactivity assays, the values are presented as the mean \pm S.E.M. The normality of the data was determined with the Kolmogorov-Smirnov test. Comparisons between two groups were performed using Student's unpaired t-tests and Mann-Whitney tests for parametric and nonparametric data, respectively. The differences between more than two groups were determined by the analysis of variance (ANOVA) and Friedman's tests for parametric and nonparametric data, respectively. If ANOVA or Friedman's test demonstrated a significant interaction between variables, post hoc analyses were performed by the multiple-comparison Bonferroni's or Dunn's correction tests, respectively. A chi-square test was performed to analyze categorical variables. Correlations were performed using Pearson's or Spearman's correlation coefficient for parametric or nonparametric data, respectively. A $p$ value $<0.05$ was considered significant for all of the tests. Statistical tests were performed with GraphPad Prism 7.0 statistical software (GraphPad Software Inc., San Diego, CA, USA).

\section{Results}

\subsection{Clinical Characteristics of the Participants}

The GDM prevalence was $7.7 \%$ in the studied population during the evaluated period (365/4731).

Age was comparable between groups, and the women with GDM were shorter in height compared to the women in group C (Table 1).

All pregnant women increased in weight during pregnancy, and patients in the O-GDM group presented higher weights during pregnancy than women in groups $\mathrm{C}$ and N-GDM (Table 1). Concerning weight gain, both groups with GDM gained less weight than group C. Additionally, women in the O-GDM group gained less weight than women in the N-GDM group (Table 1).

As for weight, BMIs increased in all pregnant women during pregnancy, and women in the O-GDM group showed higher BMIs than women in groups C and N-GDM (Table 1).

Mean arterial pressure was normal $(<106 \mathrm{mmHg})$ in all groups during pregnancy (Table 1).

Fasting glucose determined in trimester 1 was below normal levels $(<100 \mathrm{mg} / \mathrm{dL})$ in all groups (Table 1).

In the OGTTs, fasting glucose levels were normal in all the groups $(<100 \mathrm{mg} / \mathrm{dL})$. However, glucose levels were higher in women in groups N-GDM and O-GDM than in group C (Table 1). 
Table 1. Clinical characteristics of pregnant women and newborns.

\begin{tabular}{|c|c|c|c|}
\hline Variables & $\begin{array}{c}C \\
(n=41)\end{array}$ & $\begin{array}{l}\text { N-GDM } \\
(n=69)\end{array}$ & $\begin{array}{l}\text { O-GDM } \\
(n=48)\end{array}$ \\
\hline \multicolumn{4}{|l|}{ Maternal variables } \\
\hline Age (years) & $\begin{array}{c}31.7 \pm 3.8 \\
(23-36)\end{array}$ & $\begin{array}{c}34.8 \pm 4.8 \\
(25-55)\end{array}$ & $\begin{array}{c}34.6 \pm 4.5 \\
(26-42)\end{array}$ \\
\hline Height $(\mathrm{cm})$ & $\begin{array}{l}164 \pm 0.1 \\
(152-175)\end{array}$ & $\begin{array}{l}160 \pm 0.1 * \\
(149-173)\end{array}$ & $\begin{array}{c}160 \pm 0.1^{*}+ \\
(148-177)\end{array}$ \\
\hline \multicolumn{4}{|l|}{ Weight (Kg) } \\
\hline $\mathrm{T} 1$ & $\begin{array}{c}62.8 \pm 5.8 \\
(53-74)\end{array}$ & $\begin{array}{l}60.9 \pm 7.0 \\
(43.3-77)\end{array}$ & $\begin{array}{l}81.3 \pm 7.8^{*} \dagger \\
(68.8-96)\end{array}$ \\
\hline $\mathrm{T} 2$ & $\begin{array}{c}68.8 \pm 5.2 \\
(59-78)\end{array}$ & $\begin{array}{c}64.9 \pm 7.1 * \\
(45-82.8)\end{array}$ & $\begin{array}{c}82.0 \pm 9.6^{*,}+ \\
(64-115)\end{array}$ \\
\hline $\mathrm{T} 3$ & $\begin{array}{c}75.2 \pm 4.4 \ddagger \\
(68-83)\end{array}$ & $\begin{array}{c}68.8 \pm 7.2 * \ddagger \\
(51.9-88.5)\end{array}$ & $\begin{array}{c}85.2 \pm 10.0 * \dagger † \\
(66-120)\end{array}$ \\
\hline Weight gain $(\mathrm{Kg})$ & $\begin{array}{c}12.4 \pm 4.8 \\
(4-22)\end{array}$ & $\begin{array}{c}8.0 \pm 3.4^{*} \\
(0.2-12)\end{array}$ & $\begin{array}{c}5.8 \pm 3.8 *+ \\
(0.2-13.5)\end{array}$ \\
\hline \multicolumn{4}{|l|}{$\mathrm{BMI}\left(\mathrm{Kg} / \mathrm{m}^{2}\right)$} \\
\hline $\mathrm{T} 1$ & $\begin{array}{l}23.5 \pm 1.8 \\
(20.5-1.8)\end{array}$ & $\begin{array}{c}24.0 \pm 2.3 \\
(17.3-28.9)\end{array}$ & $\begin{array}{c}31.5 \pm 2.3 *+ \\
(30-38.9)\end{array}$ \\
\hline $\mathrm{T} 2$ & $\begin{array}{l}25.7 \pm 1.5 \\
(22-29.3)\end{array}$ & $\begin{array}{c}25.6 \pm 2.2 \\
(18-30)\end{array}$ & $\begin{array}{c}32.0 \pm 3.1 *+ \\
(28.9-37.3)\end{array}$ \\
\hline T3 & $\begin{array}{l}28.1 \pm 2.0 \ddagger \\
(25.7-29.9)\end{array}$ & $\begin{array}{c}26.9 \pm 2.0 * \ddagger \\
(20.8-29.8)\end{array}$ & $\begin{array}{c}33.4 \pm 3.4^{*+\dagger} \ddagger \\
(30.1-41.4)\end{array}$ \\
\hline \multicolumn{4}{|l|}{ Mean arterial pressure (mm Hg) } \\
\hline $\mathrm{T} 1$ & $\begin{array}{c}81.5 \pm 5.9 \\
(73.3-93.3)\end{array}$ & $\begin{array}{c}81.7 \pm 7.1 \\
(63.3-95.6)\end{array}$ & $\begin{array}{l}79.1 \pm 5.6+ \\
(67.3-86.7)\end{array}$ \\
\hline $\mathrm{T} 2$ & $\begin{array}{c}82.2 \pm 5.9 \\
(73.3-93.3)\end{array}$ & $\begin{array}{c}88.4 \pm 9.7 * \\
(66.7-103.3)\end{array}$ & $\begin{array}{c}80.5 \pm 7.5+ \\
(66.7-93.3)\end{array}$ \\
\hline $\mathrm{T} 3$ & $\begin{array}{l}86.4 \pm 5.3 \ddagger \\
(73.3-96.7)\end{array}$ & $\begin{array}{c}83.1 \pm 6.3 * \\
(66.7-101.7)\end{array}$ & $\begin{array}{l}81.4 \pm 7.5 * \\
(70-95)\end{array}$ \\
\hline Fasting glycemia (mg/dL) & $\begin{array}{c}84.0 \pm 4.0 \\
(80-88)\end{array}$ & $\begin{array}{c}85.5 \pm 10.9 \\
(63-103)\end{array}$ & $\begin{array}{c}84.3 \pm 8.4 \\
(69-98)\end{array}$ \\
\hline \multicolumn{4}{|l|}{ OGTT (mg/dL) } \\
\hline Basal glycemia & $\begin{array}{c}77.5 \pm 4.3 \\
(69-85)\end{array}$ & $\begin{array}{c}81.8 \pm 8.4 * \\
(70-110)\end{array}$ & $\begin{array}{c}87.2 \pm 14.2 * \dagger \\
(70-129)\end{array}$ \\
\hline Glycemia at 2 hours & $\begin{array}{c}106.4 \pm 17.4 \\
(75-139)\end{array}$ & $\begin{array}{c}157.7 \pm 15.7 \text { * } \\
(140-201)\end{array}$ & $\begin{array}{c}154.7 \pm 17.3^{*} \\
(141-200)\end{array}$ \\
\hline Insulin $(\mu \mathrm{UI} / \mathrm{ml})$ & $\mathrm{C}^{\prime}=\mathrm{s}^{\prime}$ & $\begin{array}{c}9.5 \pm 5.1 \\
(2.7-27.4)\end{array}$ & $\begin{array}{c}11.9 \pm 6.5^{*} \\
(3.3-26.6)\end{array}$ \\
\hline $\mathrm{HbA} 1 \mathrm{c} \%$ & - & $\begin{array}{c}5.7 \pm 2.0 \\
(2.4-14.4)\end{array}$ & $\begin{array}{c}5.9 \pm 1.4 \\
(4.9-13.5)\end{array}$ \\
\hline HOMA-IR & - & $\begin{array}{l}2.0 \pm 1.5 \\
(0.5-5.2)\end{array}$ & $\begin{array}{l}3.1 \pm 2.8 * \\
(0.8-12.9)\end{array}$ \\
\hline \multicolumn{4}{|l|}{ Newborn variables } \\
\hline Sex (female/male) & $25 / 16$ & $37 / 32$ & $21 / 27$ \\
\hline Gestational age (weeks) & $\begin{array}{c}38.5 \pm 1.0 \\
(37-40)\end{array}$ & $\begin{array}{c}38.6 \pm 3 \\
(36-40)\end{array}$ & $\begin{array}{c}38.2 \pm 3.2 \\
(37-40)\end{array}$ \\
\hline Height $(\mathrm{cm})$ & $\begin{array}{l}49.5 \pm 1.7 \\
(45-52.5)\end{array}$ & $\begin{array}{c}49.9 \pm 2.0 \\
(46-52)\end{array}$ & $\begin{array}{c}49.5 \pm 1.5 \\
(48-52)\end{array}$ \\
\hline Birth weight (grams) & $\begin{array}{c}3308 \pm 382 \\
(2600-4060)\end{array}$ & $\begin{array}{c}3286 \pm 412 \\
(2430-3830)\end{array}$ & $\begin{array}{c}3243 \pm 405 \\
(2700-3950)\end{array}$ \\
\hline Ponderal index (grams/cm $\left.\mathrm{cm}^{3} 100\right)$ & $\begin{array}{c}2.6 \pm 0.2 \\
(2.35-3.02)\end{array}$ & $\begin{array}{c}2.7 \pm 0.2 \\
(2.43-3.14)\end{array}$ & $\begin{array}{c}2.7 \pm 0.3 \\
(2.3-3.16)\end{array}$ \\
\hline
\end{tabular}

Control $(\mathrm{C}, n=41)$ and nonobese $(\mathrm{N})$ or obese $(\mathrm{O})$ women with gestational diabetes mellitus (GDM, $n=117)$ were included. Clinical variables at the 1st trimester (T1, 0-14 weeks of gestation), 2nd trimester (T2, 14-28 weeks of gestation) or 3rd trimester (T3, 28-40 weeks of gestation) of pregnancy were tabulated. Weight, body mass index (BMI) and mean arterial pressure were determined for all groups at T1, T2 and T3. Maternal age, height and fasting glycemia were determined in all groups at T1. The insulin, glycosylated hemoglobin (HbA1c) and homeostatic model assessment for insulin resistance (HOMA-IR) levels were determined, and the oral glucose tolerance test (OGTT) was performed in all GDM groups at T2. At birth, neonatal sex, gestational age, height, weight and ponderal index were determined. Normal values or ranges for the measured variables are as follows: mean arterial pressure $<106 \mathrm{mmHg}$, OGTT basal glycemia $<100 \mathrm{mg} / \mathrm{dL}$, OGTT glycemia at 2 hours $<140 \mathrm{mg} / \mathrm{dL}$, insulin 2.6-24.9 $\mu \mathrm{UI} / \mathrm{ml}$, $\mathrm{HbA} 1 \mathrm{c}<6.0 \%$ and HOMA-IR until 2.6. Data are presented as the mean \pm S.D. (range). Significant differences were considered with $p<0.05$. * respect to $\mathrm{C}, \dagger$ respect to the $\mathrm{N}-\mathrm{GDM}$ group, $\ddagger$ respect to T1. 
The two-hour glucose levels after a $75 \mathrm{~g}$ glucose load were above normal levels ( $<140 \mathrm{mg} / \mathrm{dL})$ in all women with GDM and higher compared to women in group C (Table 1).

Insulin and $\mathrm{HbA} 1 \mathrm{c}$ levels were only determined in women with GDM. These values were normal (range 2.6-24.9 $\mu \mathrm{UI} / \mathrm{ml}$ for insulin and $<6.0 \%$ for $\mathrm{HbA1c}$ ), even though women in the O-GDM group showed higher levels of insulin than women in the N-GDM group (Table 1). Additionally, HOMA-IR was above normal levels (> 2.6) in women in the O-GDM group relative to women in the N-GDM group (Table 1).

Newborn variables such as sex, gestational age, height, birth weight and ponderal index were similar across all groups (Table 1).

\subsection{Effects of Obesity and GDM on the Lipid Profile of Pregnant Women}

TC, TG, HDL, LDL and VLDL were measured in group $C$ and in women with GDM during pregnancy (Figure 1). As shown in Figure 1A, 1C and 1D, during T1 no changes were observed between groups C, N-GDM and O-GDM concerning TC $(184.6 \pm 33.5,183.5 \pm 36.1$ and $184.7 \pm 25.4 \mathrm{mg} / \mathrm{dL}$, respectively), HDL $(66.3 \pm 12.8,63.8 \pm 13.1$ and $61.9 \pm 14.8 \mathrm{mg} / \mathrm{dL}$, respectively) or LDL $(104.2 \pm 30.6$, $94.6 \pm 28.7$ and $93.4 \pm 15.4 \mathrm{mg} / \mathrm{dL}$, respectively) levels, respectively. However, an increase in TG was observed in the O-GDM group compared to group C $(151.1 \pm 64.1$ versus $102.7 \pm 39.8 \mathrm{mg} / \mathrm{dL})$ (Figure 1B); a similar effect was also observed in VLDL levels (30.2 \pm 12.8 versus $20.6 \pm 7.9 \mathrm{mg} / \mathrm{dL}$ ) (Figure 1E). In T2, TC levels in the O-GDM group were lower than those in group C (203.5 \pm 36.6 versus $237.7 \pm 38.6 \mathrm{mg} / \mathrm{dL}$ ) (Figure 1A). This change was associated with lower levels of HDL $(66.6 \pm 17.1$ versus $79.1 \pm 22.4 \mathrm{mg} / \mathrm{dL}$ ) (Figure 1C) and LDL $(99.1 \pm 27.9$ versus $125.2 \pm 32.1 \mathrm{mg} / \mathrm{dL})$ in the O-GDM group compared to group C (Figure 1D). Moreover, TG levels were higher in the N-GDM and O-GDM groups than in group C $(205.7 \pm 94.5,189.1 \pm 60.3$ and $167.9 \pm 59.9 \mathrm{mg} / \mathrm{dL}$, respectively) (Figure 1B). VLDL levels were higher in the N-GDM and O-GDM groups than in group C $(41.1 \pm 18.9,37.8 \pm 12.0$ and $33.1 \pm 12.3 \mathrm{mg} / \mathrm{dL}$, respectively) (Figure 1E). In T3, TC and HDL in the N-GDM and O-GDM groups were lower than those in group C (TC: $244.9 \pm 46.1,231.8 \pm 49.1$ and $263.1 \pm 48.2 \mathrm{mg} / \mathrm{dL}$, respectively; HDL: $66.2 \pm 18.8,65.6 \pm 17.1$ and $76.3 \pm 18.8 \mathrm{mg} / \mathrm{dL}$, respectively) (Figure 1A, 1C). LDL were lower in the O-GDM group compared to group C $(122.2 \pm 40.8$ versus $137.9 \pm 37.3 \mathrm{mg} / \mathrm{dL})$ (Figure 1D). No significant changes were observed in TG or VLDL in the N-GDM or O-GDM groups compared with group C (TG: $229.4 \pm 86.3,224.8 \pm 71.0$ and $241.5 \pm 84.2 \mathrm{mg} / \mathrm{dL}$, respectively; VLDL: $45.9 \pm 17.2$, $44.4 \pm 13.3$ and $48.6 \pm 23.5 \mathrm{mg} / \mathrm{dL}$, respectively) (Figure 1B, 1E).

A

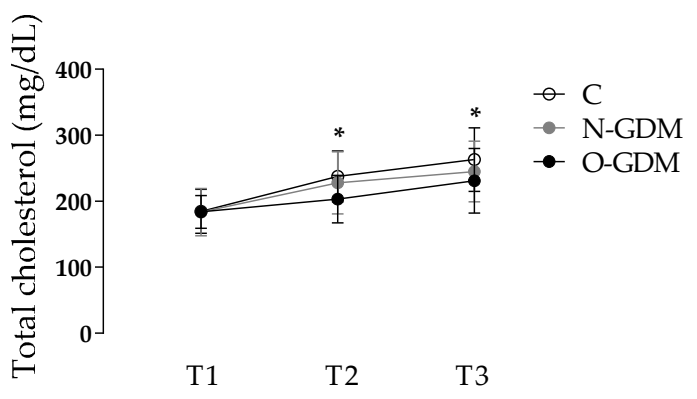

B

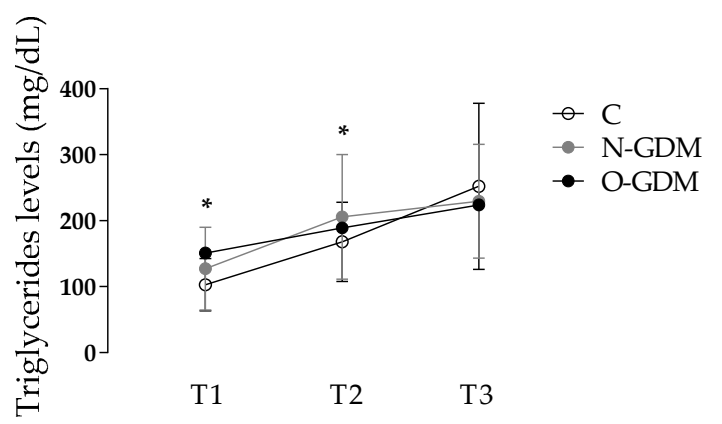

Figure 1. Cont. 
C

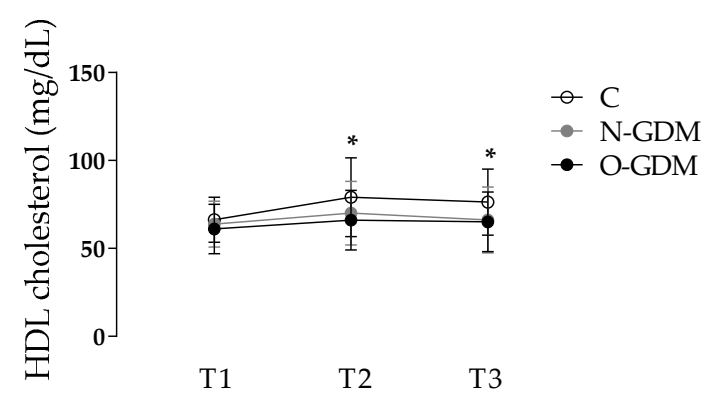

D

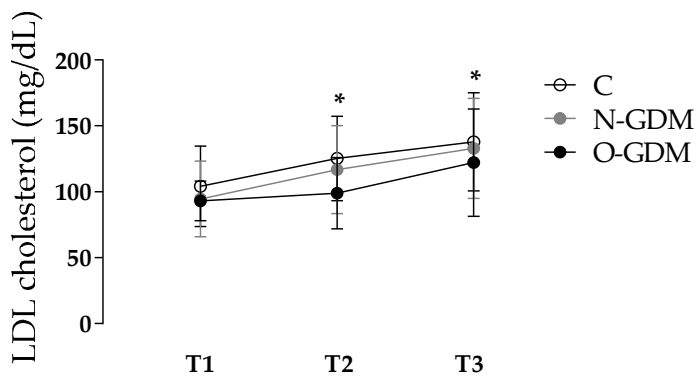

E

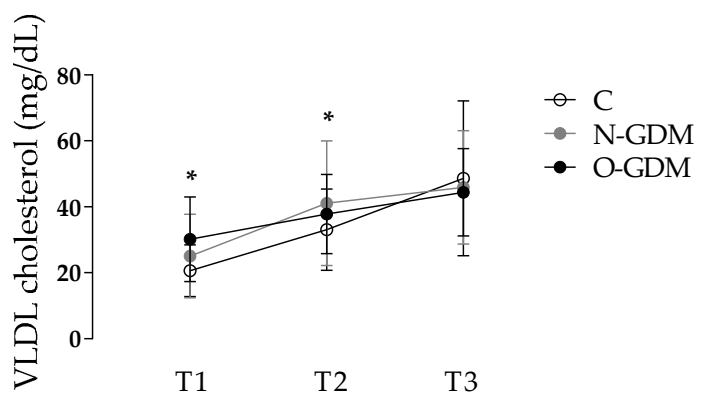

Figure 1. Lipid profile during pregnancy in the control group and nonobese or obese women with gestational diabetes mellitus. Lipid determination was performed in the control women (C, $n=41)$ group and nonobese $(\mathrm{N}, n=69)$ or obese $(\mathrm{O}, n=48)$ women with gestational diabetes mellitus (GDM). Lipid determination was performed at the 1st (T1, 0-14 weeks of gestation), 2nd (T2, 14-28 weeks of gestation) and 3rd trimester (T3, 28-40 weeks of gestation) of pregnancy. (A) TC: total cholesterol, (B) TG: triglycerides, (C) HDL: high density lipoproteins, (D) LDL: low density lipoproteins, (E) VLDL: very low density lipoproteins, T: trimester. Values are the mean \pm S.D. and units are $\mathrm{mg} / \mathrm{dL}$. Significant differences were considered with ${ }^{*} p<0.05$.

\subsection{Correlation Between Maternal BMI and Lipid Levels}

There was no correlation between BMI and TC, TG, HDL, LDL or VLDL levels at T1, T2 or T3 in group C or groups with GDM (Table 2).

\subsection{Effect of GDM Treatments on Glycemic Control}

The treatments for GDM were only diet (14.1\%), diet plus metformin $(13.3 \%)$ or insulin $(53.5 \%)$, or insulin plus metformin (19.1\%), depending on the criteria established by clinical staff and the achievement of metabolic targets. In total, $15.7 \%$ of the N-GDM group used diet as treatment compared to $11.6 \%$ of the O-GDM group. A higher percentage of the N-GDM group (18.4\%) used diet plus metformin compared to $7 \%$ of the O-GDM group. In total, $55.3 \%$ of the N-GDM group used diet plus insulin compared to $53.5 \%$ of the O-GDM group. A lower percentage of the N-GDM group received the three treatments together (10.5\%) compared to $27.9 \%$ in the O-GDM group (Figure 2A).

Glycemic control at the end of pregnancy was achieved under the different treatment options, and the results were similar between the N-GDM and O-GDM groups (Figure 2B). No significant differences were observed in non-fasting glucose levels in T3 for women in N-GDM and O-GDM groups treated with diet $(91.9 \pm 16.4$ and $96.3 \pm 14.0 \mathrm{mg} / \mathrm{dL}$, respectively), in those who used diet and metformin $(98.4 \pm 39.6$ and $92 \pm 3.0 \mathrm{mg} / \mathrm{dL}$, respectively), in women who used diet plus insulin $(80.8 \pm 8.5$ and $84.7 \pm 12.0 \mathrm{mg} / \mathrm{dL}$, respectively), or in those who used diet, metformin and insulin $(80.8 \pm 9.1$ and $85.4 \pm 13.5 \mathrm{mg} / \mathrm{dL}$, respectively) (Figure 2B). 
Table 2. Correlation between lipid levels and body mass index during pregnancy in women with gestational diabetes mellitus.

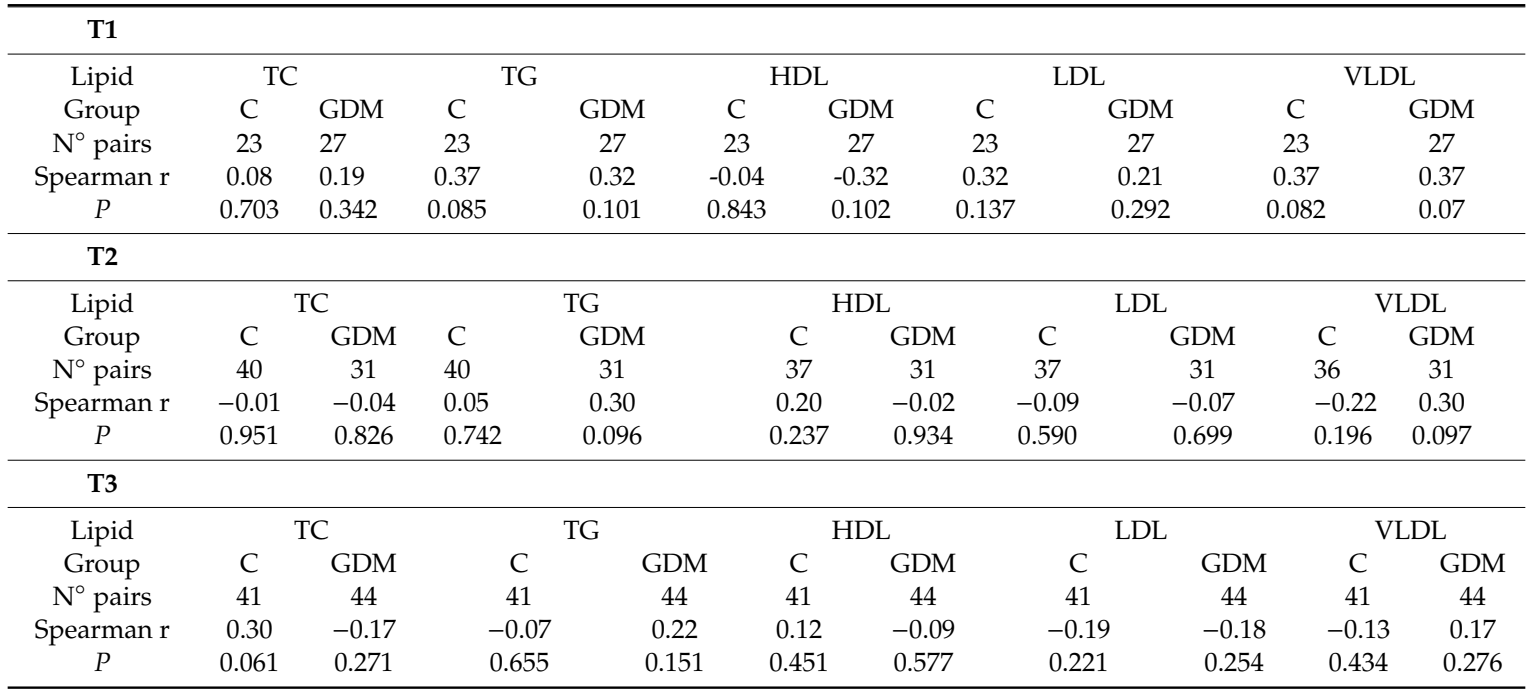

Control (C) women or women with gestational diabetes mellitus (GDM) were included. Spearman correlation analyses between body mass index (BMI) and lipid levels during the 1st trimester (T1, 0-14 weeks of gestation), 2nd trimester (T2, 14-28 weeks of gestation) or 3rd trimester (T3, 28-40 weeks of gestation) of pregnancy were performed. For each trimester, the following is shown: Group, pairs correlated, values for Spearman $\mathrm{r}$ and $P$. TC: total cholesterol, TG: triglycerides, HDL: high density lipoproteins, LDL: low density lipoproteins, VLDL: very low density lipoproteins. Significant differences were considered with $p<0.05$.

A

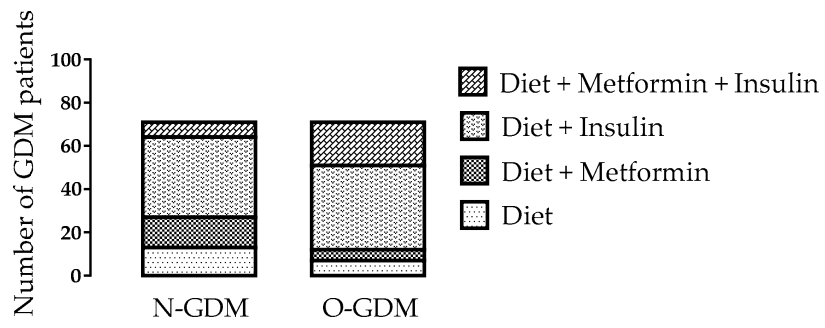

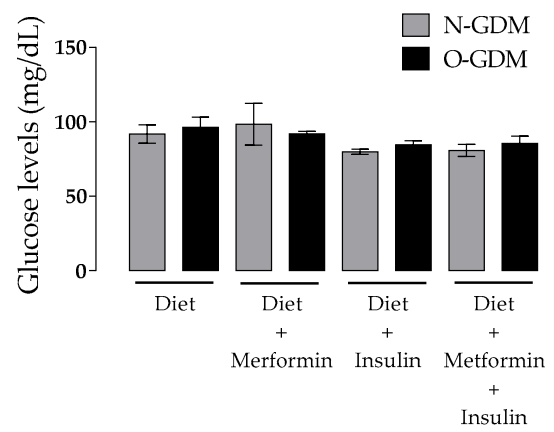

Figure 2. Effect of gestational diabetes mellitus treatment on glucose levels in nonobese and obese pregnant women at term. Glucose levels were determined in nonobese $(\mathrm{N}, n=69)$ or obese $(\mathrm{O}, n=48)$ women with gestational diabetes mellitus (GDM) pregnancy. (A) Frequency of treatments in women with GDM, $\chi^{2}=4.263, p=0.039$ for diet plus metformin and $\chi^{2}=6.259, p=0.012$ for diet plus insulin and metformin. (B) Glucose levels determined during the 3rd trimester after different GDM treatments. GDM treatments were as follows: diet, diet plus metformin, diet plus insulin and diet plus insulin and metformin. Values are the mean \pm S.D. Significant differences were considered with ${ }^{*} p<0.05$.

\subsection{Effect of GDM Treatment on Lipid Levels}

Lipid levels were determined in women with GDM at T3 with groups categorized according to their GDM treatment, as discussed in Section 3.4.

Treatment with diet was associated with lower TC levels in the O-GDM group compared to the N-GDM group (220.7 \pm 54.4 versus $270.5 \pm 40.1 \mathrm{mg} / \mathrm{dL}$ ) (Figure 3A) as well as lower LDL levels $(119.3 \pm 26.6$ versus $158.8 \pm 35.7 \mathrm{mg} / \mathrm{dL}$ ) (Figure 3B). In the N-GDM group compared to the O-GDM group, no additional changes in TC $(253.4 \pm 37.1$ versus $185.6 \pm 21.5 \mathrm{mg} / \mathrm{dL})$ or LDL levels $(130.3 \pm 30.5$ versus $84.2 \pm 29.8 \mathrm{mg} / \mathrm{dL}$ ) were observed in women treated with diet plus metformin with respect to diet alone. Interestingly, treatment with diet plus insulin was associated with augmented TC levels 
in the O-GDM group with respect to the N-GDM group ( $250.4 \pm 50.5$ versus $236.0 \pm 45.7 \mathrm{mg} / \mathrm{dL})$ as well as increased LDL levels ( $134.5 \pm 46.1$ versus $128.7 \pm 40.2 \mathrm{mg} / \mathrm{dL}$ ) (Figure 3B). Furthermore, in women treated with diet plus metformin and insulin, TC and LDL levels were comparable in both the N-GDM and O-GDM groups (TC: $234.3 \pm 65.2$ versus $206.1 \pm 32.3 \mathrm{mg} / \mathrm{dL}$; LDL: $116.3 \pm 21.7$ versus $105.4 \pm 26.9 \mathrm{mg} / \mathrm{dL}$ ) (Figure 3A, 3B).

A

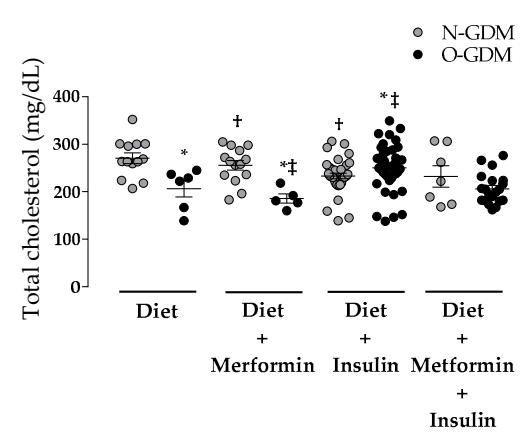

C

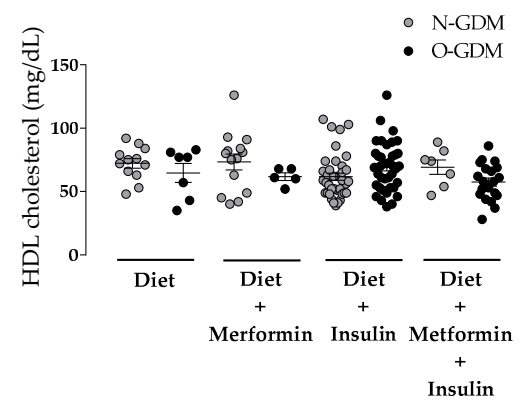

B

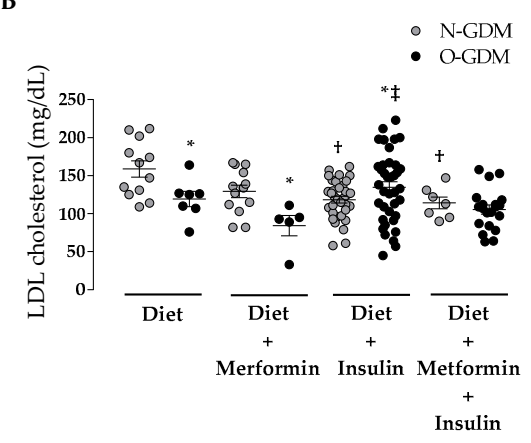

D

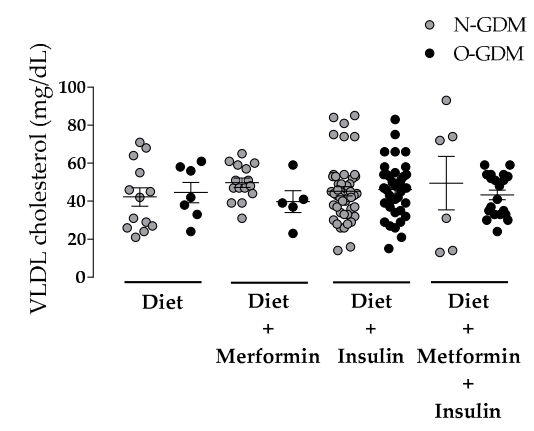

E

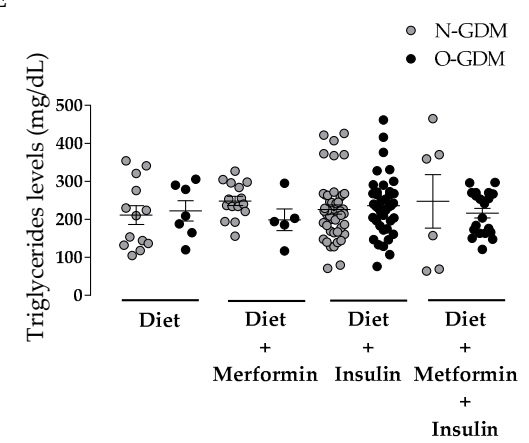

Figure 3. Effect of different treatments for gestational diabetes mellitus on maternal lipid levels in nonobese and obese pregnant women at term. Lipid determination was performed at the 3rd trimester in nonobese ( $\mathrm{N}, n=50)$ or obese $(\mathrm{O}, n=46)$ women with gestational diabetes mellitus (GDM). GDM treatments were diet, diet plus metformin, diet plus insulin and diet plus insulin and metformin. (A) Total cholesterol levels, (B) low density lipoproteins cholesterol levels (LDL), (C) high density lipoproteins cholesterol levels (HDL), (D) triglycerides levels and (E) very low density lipoproteins cholesterol levels (VLDL). Values are the mean \pm S.D. Significant differences were considered with $p<0.05$. * respect to the N-GDM group, + respect to diet in the N-GDM group, $\ddagger$ respect to diet in the O-GDM group.

No changes were observed between groups with GDM and their received treatments in HDL (Figure 3C), VLDL (Figure 3D) or TG (Figure 3E). 
Additional analysis of the same data showed that the different treatments had differentiated effects on the lipid profile in the N-GDM or O-GDM groups. Thus, in the N-GDM group, treatment with diet plus insulin was associated with lower TC levels compared to those treated with diet $(236.0 \pm 45.7$ versus $270.5 \pm 40.1 \mathrm{mg} / \mathrm{dL}$ ) (Figure 3A). This result was associated with decreased LDL levels in those in the N-GDM group treated with diet plus insulin and treated with diet plus insulin and metformin with respect to those treated with $\operatorname{diet}(128.7 \pm 40.2,116.3 \pm 21.7$ and $158.1 \pm 35.7 \mathrm{mg} / \mathrm{dL}$, respectively) (Figure 3B). In regards to TC in the O-GDM group, higher levels were determined in those in the O-GDM group treated with diet plus insulin compared to those treated with diet $(250.4 \pm 50.5$ versus $220.7 \pm 54.4 \mathrm{mg} / \mathrm{dL}$ ) without changes in LDL or other lipoproteins.

\subsection{Effect of GDM and Maternal Lipids on Human Umbilical Vein Reactivity}

Vascular reactivity was evaluated in human umbilical vein rings from women in groups $C$ and N-GDM with NTC or HTC at term (Table 3). All groups were comparable in maternal age, height, weight, weight gain, BMI, mean arterial pressure and glycemia during the first trimester (Table 3). OGTT results were different in the N-GDM (NTC and HTC) group compared to group C (NTC and HTC). TC was increased in both HTC groups compared to NTC groups (Table 3).

Table 3. Clinical characteristics of pregnant womem and newborns recruited for feto-placental vascular reactivity assays.

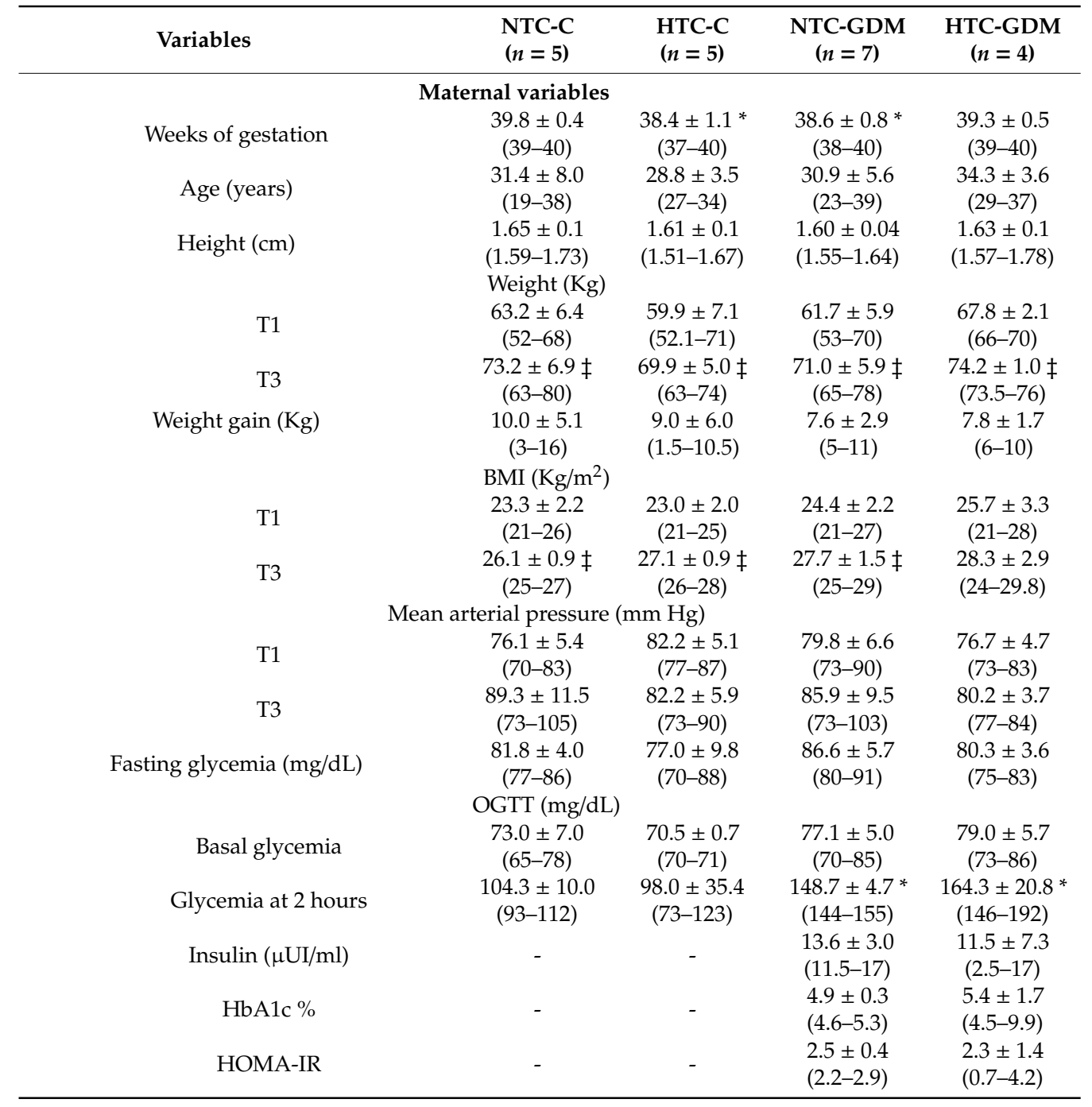


Table 3. Cont

\begin{tabular}{|c|c|c|c|c|}
\hline Variables & $\begin{array}{l}\text { NTC-C } \\
(n=5)\end{array}$ & $\begin{array}{l}\text { HTC-C } \\
(n=5)\end{array}$ & $\begin{array}{c}\text { NTC-GDM } \\
(n=7)\end{array}$ & $\begin{array}{l}\text { HTC-GDM } \\
\quad(n=4)\end{array}$ \\
\hline \multicolumn{5}{|c|}{ Lipids (mg/dL) } \\
\hline Total cholesterol & $\begin{array}{c}223 \pm 29.2 \\
(187-258)\end{array}$ & $\begin{array}{c}308 \pm 22.3 \\
(292-347)\end{array}$ & $\begin{array}{l}232 \pm 19.8 \\
(202-256)\end{array}$ & $\begin{array}{c}337 \pm 44.5^{*}+ \\
(298-376)\end{array}$ \\
\hline Triglycerides & $\begin{array}{c}276 \pm 45.4 \\
(201-317)\end{array}$ & $\begin{array}{c}235 \pm 96.3 \\
(184-394)\end{array}$ & $\begin{array}{c}219 \pm 73.3 \\
(153-331)\end{array}$ & $\begin{array}{c}268 \pm 76.6 \\
(172-335)\end{array}$ \\
\hline High density lipoproteins & $\begin{array}{c}61 \pm 14.5 \\
(49-84)\end{array}$ & $\begin{array}{c}53 \pm 8.0 \\
(47-67)\end{array}$ & $\begin{array}{c}72 \pm 14.0 \\
(50-91)\end{array}$ & $\begin{array}{l}83 \pm 23.3 \\
(50-110)\end{array}$ \\
\hline Low density lipoproteins & $\begin{array}{l}119 \pm 18.1 \\
(101-142)\end{array}$ & $\begin{array}{c}208 \pm 25.2 \\
(166-234)\end{array}$ & $\begin{array}{l}147 \pm 27.5 \\
(109-176)\end{array}$ & $\begin{array}{l}159 \pm 48.6 \\
(113-220)\end{array}$ \\
\hline Very low density lipoproteins & $\begin{array}{c}43 \pm 24.4 \\
(13-63)\end{array}$ & $\begin{array}{c}47 \pm 18.7 \\
(31-79)\end{array}$ & $\begin{array}{c}46 \pm 13.2 \\
(33-66)\end{array}$ & $\begin{array}{c}54 \pm 15.5 \\
(34-67)\end{array}$ \\
\hline \multicolumn{5}{|c|}{ Newborn variables } \\
\hline Sex (female/male) & $2 / 3$ & $1 / 4$ & $4 / 3$ & $2 / 2$ \\
\hline Height $(\mathrm{cm})$ & $\begin{array}{c}51.6 \pm 1.2 \\
(50-53)\end{array}$ & $\begin{array}{c}50.2 \pm 1.3 \\
(49-53)\end{array}$ & $\begin{array}{c}50.3 \pm 1.7 \\
(47-52)\end{array}$ & $\begin{array}{c}50.6 \pm 1.4 \\
(49-52)\end{array}$ \\
\hline Birth weight (grams) & $\begin{array}{l}3500 \pm 199.1 \\
(3320-3810)\end{array}$ & $\begin{array}{c}3220 \pm 346.5 \\
(2890-3800)\end{array}$ & $\begin{array}{l}3287 \pm 312.1 \\
(2640-3610)\end{array}$ & $\begin{array}{c}3545 \pm 438.5 \\
(2900-3860)\end{array}$ \\
\hline Ponderal index $\left(\right.$ grams $\left./ \mathrm{cm}^{3} \times 100\right)$ & $\begin{array}{l}2.5 \pm 0.1 \\
(2.4-2.7)\end{array}$ & $\begin{array}{l}2.6 \pm 0.1 \\
(2.4-2.7)\end{array}$ & $\begin{array}{l}2.6 \pm 0.2 \\
(2.3-2.8)\end{array}$ & $\begin{array}{l}2.7 \pm 0.3 \\
(2.5-3.1)\end{array}$ \\
\hline
\end{tabular}

Control (C) women with normal total cholesterol (NTC) (NTC-C, $n=5$ ), high total cholesterol (HTC) (HTC-C, $n=5$ ), women with gestational diabetes mellitus (GDM) and NTC (NTS-GDM, $n=7$ ) and with GDM and HTC (HTC-GDM, $n=4$ ) were included. Clinical variables at the 1st trimester (T1, 0-14 weeks of gestation), 2nd trimester (T2, 14-28 weeks of gestation) or 3rd trimester (T3, 28-40 weeks of gestation) of pregnancy were tabulated. Weight, body mass index (BMI) and mean arterial pressure were determined in all groups at T1, T2 and T3. Maternal age, height and fasting glycemia were determined in all groups at T1. Insulin, glycosylated hemoglobin (HbA1c), oral glucose tolerance test (OGTT) and homeostatic model assessment for insulin resistance (HOMA-IR) were performed in all GDM groups at T2. Maternal lipids were determined at T3. At birth, neonatal sex, gestational age, height, weight, and ponderal index were determined. Normal values or ranges for the measured variables are as follows: mean arterial pressure $<106 \mathrm{mmHg}$, OGTT basal glycemia $\leq 100 \mathrm{mg} / \mathrm{dL}$, OGTT glycemia at 2 hours $\leq 140 \mathrm{mg} / \mathrm{dL}$, insulin 2.6-24.9 $\mu \mathrm{UI} / \mathrm{ml}, \mathrm{HbA} 1 \mathrm{c}<6.0 \%$, HOMA-IR until 2.6, and HTC $\geq 280 \mathrm{mg} / \mathrm{dL}$. Data are presented as the mean \pm S.D. (range). Significant differences were considered with $p<0.05 .{ }^{*}$ respect to NTC-C, $\ddagger$ respect to T1, † respect to NTC-GDM.

The vascular rings were challenged to relaxation with CGRP in a dose-dependent manner. Maximal relaxation $\left(\mathrm{R}_{\max }\right)$ in the N-GDM (including NTC and HTC) group was lower than that in the C (including NTC and HTC) group (18.3 \pm 1.9 versus $32.1 \pm 5.2 \%$ ) (Figure 4A, Table 4). Moreover, the half maximal effective concentration $\left(\mathrm{EC}_{50}\right)$ in response to CGRP in the vein rings from the N-GDM group was comparable to that of group C $(7.4 \pm 0.16$ versus $7.4 \pm 0.18 \mathrm{nM})$ (Figure $4 \mathrm{~A}$, Table 4$)$.

Table 4. The impact of maternal high cholesterol levels on dilation of human umbilical vein rings.

\begin{tabular}{|c|c|c|c|c|c|c|}
\hline \multirow{2}{*}{$\begin{array}{c}\text { Parameter } \\
\text { Group }\end{array}$} & \multicolumn{6}{|c|}{ CGRP } \\
\hline & $\begin{array}{l}\text { Control } \\
(n=10)\end{array}$ & $\begin{array}{c}\text { GDM } \\
(n=11)\end{array}$ & $\begin{array}{l}\text { NTC-C } \\
(n=5)\end{array}$ & $\begin{array}{c}\text { HTC-C } \\
(n=5)\end{array}$ & $\begin{array}{c}\text { NTC-GDM } \\
(n=7)\end{array}$ & $\begin{array}{l}\text { HTC-GDM } \\
(n=4)\end{array}$ \\
\hline $\mathrm{EC}_{50}$ average (nM) & $7.4 \pm 0.18$ & $7.4 \pm 0.16$ & $7.6 \pm 0.2$ & $8.4 \pm 0.2 *$ & $10.7 \pm 0.3^{*}+$ & $6.5 \pm 0.2^{*}+\neq \ddagger$ \\
\hline $\mathbf{R}_{\max }$ average $(\%)$ & $32.1 \pm 5.2$ & $18.3 \pm 1.9^{*}$ & $39.1 \pm 6.7$ & $18.2 \pm 2 *$ & $28.7 \pm 2.4+$ & $15.3 \pm 1.8^{*}+{ }^{+}$ \\
\hline
\end{tabular}

Nonobese Control (C, $n=10)$ women or those with gestational diabetes mellitus (GDM, $n=11$ ) were included. The women were categorized as having normal total cholesterol (NTC, TC $<280 \mathrm{mg} / \mathrm{dL}$ ) or high total cholesterol (HTC, TC $\geq 280 \mathrm{mg} / \mathrm{dL}$ ) levels. Human umbilical vein rings were obtained at term from the different groups. CGRP, calcitonin gene-related peptide. $\mathrm{EC}_{50}$, half maximal effective concentration. $\mathrm{R}_{\max }$, maximal relaxation. Values are the mean \pm S.E.M. $(n=4-7)$. Significant differences were considered with $p<0.05 .{ }^{*}$ respect to the C or NTC-C groups, + respect to the HTC-C group, $\ddagger$ respect to the NTC-GDM group.

Interestingly, the $\mathrm{R}_{\max }$ of NOS-dependent relaxation in the UV rings from the women in group $\mathrm{C}$ with NTC was higher than those determined to have HTC in group C $(39.1 \pm 6.7$ versus $16.7 \pm 2.0 \%)$ (Figure 4B, Table 4). In addition, the $\mathrm{R}_{\max }$ in women from the N-GDM group with NTC was higher than those determined to have HTC in the N-GDM group (28.7 \pm 2.4 versus $15.3 \pm 1.8 \%$ ) (Figure $4 \mathrm{~B}$, Table 4). No differences were observed between women in the group C with NTC and women in the 
N-GDM group with NTC (39.1 \pm 6.7 versus $28.7 \pm 2.4)$ (Figure $4 \mathrm{~B}$, Table 4$)$. However, the $\mathrm{R}_{\max }$ in women from group $\mathrm{C}$ with HTC was higher than that of women from the N-GDM group with HTC $\left(16.7 \pm 2.0\right.$ versus $15.3 \pm 1.8 \%$ ) (Figure $4 \mathrm{~B}$, Table 4). Accordingly, the $\mathrm{EC}_{50}$, in response to CGRP in vein rings from the women in group $\mathrm{C}$ with $\mathrm{HTC}$, was higher than that of the women in group $\mathrm{C}$ with NTC $(8.4 \pm 0.2$ versus $7.6 \pm 0.2 \mathrm{nM})$ (Figure $4 \mathrm{~B}$, Table 4$)$. The $\mathrm{EC}_{50}$ from women in the N-GDM group with HTC was lower than that determined in women from the N-GDM and C groups with NTC (6.5 \pm 0.2 , $10.7 \pm 0.3$ and $7.6 \pm 0.2 \mathrm{nM}$, respectively) (Figure $4 \mathrm{~B}$, Table 4 ). Finally, the $\mathrm{EC}_{50}$ from women in the N-GDM group with HTC was lower than that of the women from group C with HTC $(6.5 \pm 0.2$ versus $8.4 \pm 0.2 \mathrm{nM})$.

A

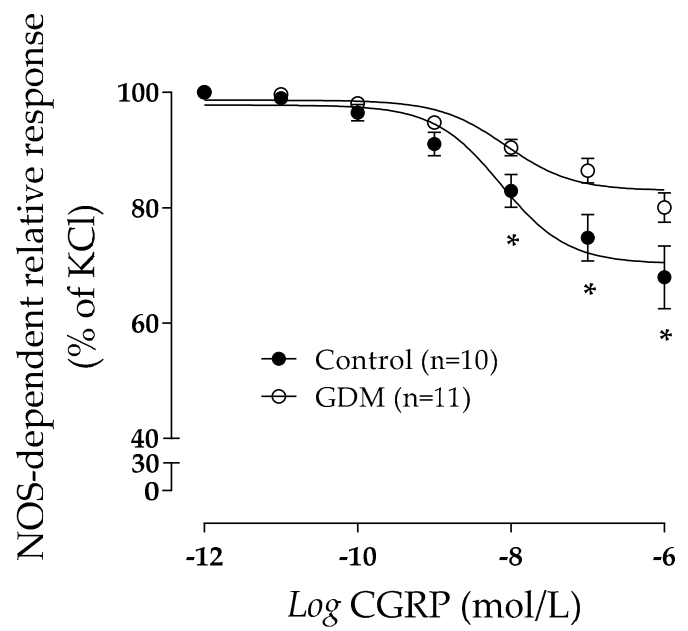

B

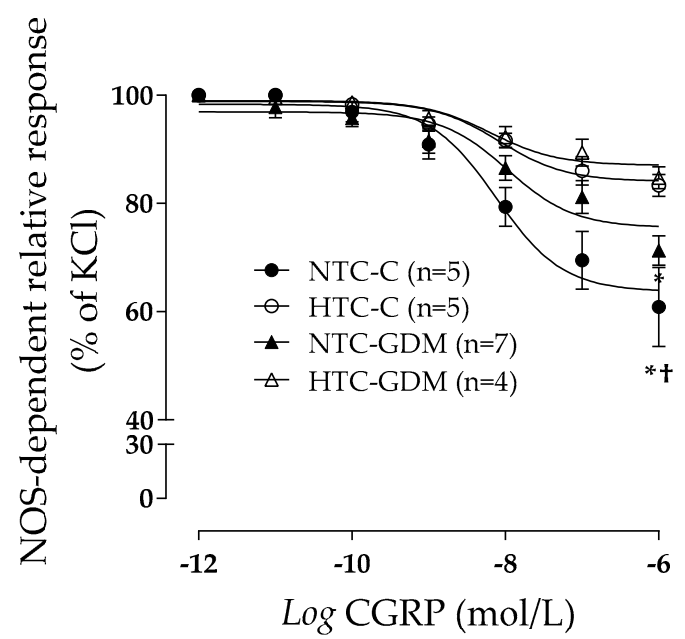

Figure 4. Impact of high total cholesterol levels on the dilation of human umbilical vein rings from nonobese control women and women with gestational diabetes mellitus. Human umbilical vein rings were obtained at term from nonobese pregnant women from the control (C) group or those with gestational diabetes mellitus (GDM). The women were categorized as having normal total cholesterol (NTC, TC $<280 \mathrm{mg} / \mathrm{dL}$ ) or high total cholesterol (HTC, TC $\geq 280 \mathrm{mg} / \mathrm{dL}$ ) levels. (A) Relaxation was determined in umbilical vein rings from the C $(n=10)$ or GDM $(n=11)$ groups in response to calcitonin gene-related peptide (CGRP, $0.001-1000 \mathrm{nmol} / \mathrm{L}, 5$ minutes). Rings were pre-constricted with $32.5 \mathrm{mmol} / \mathrm{L} \mathrm{KCl}$ in the absence or presence of $100 \mu \mathrm{mol} / \mathrm{L} \mathrm{NG-nitro-L-arginine} \mathrm{methyl} \mathrm{ester} \mathrm{(L-NAME,}$ 20 minutes), and the percentage of inhibition of maximal dilation was graphed. (B) The same samples from A were categorized as NTC-C $(n=5), \operatorname{HTC}-\mathrm{C}(n=5)$, NTC-GDM $(n=7)$ or HTC-GDM $(n=4)$ and vascular dilation was assayed like that in A. Values are mean \pm S.E.M. Significant differences were considered with $p<0.05$. ${ }^{*}$ respect to C or NTC-C, + respect to HTC-C. 


\section{Discussion}

The current study proposes, for the first time, the relevance of making a differentiation in the GDM treatment according to the maternal weight state, in order to recommend a specific treatment for each group. Additionally, this investigation reinforces the importance of measuring lipids during pregnancy as a routine exam. However, this study has some limitations related to the small sample size in each subgroup and the cross-sectional nature of the study, which limited the interpretation of the results.

The prevalence of GDM was $7.7 \%$ in our study group. This investigation was conducted in a sample of adequately managed women with GDM in terms of recommended gestational weight gain [28] and glycemic control [1], based on three therapeutic options, including only diet or diet plus metformin and/or insulin $[21,36,57,58]$. The lipid profile of women in the N-GDM and O-GDM groups changed during pregnancy. However, women developed dyslipidemia from T1 in the O-GDM group and from T2 in the N-GDM group, which in both cases persisted until T3, and these changes were independent of BMI. While all GDM subgroups of treatment options showed proper metabolic control when evaluated at T3, we observed differential modulation of TC and LDL levels between obese and nonobese patients with GDM. Moreover, in those of the N-GDM group with normal glucose and high TC levels, vasodilation of the umbilical vein rings was impaired compared to that of women with normal TC levels. These data suggest that GDM treatments differentially modulate TC levels in nonobese and obese pregnant women, which could be an important factor in modulating feto-placental endothelial function.

Concerning the prevalence of GDM, the result of this study was comparable to those described in other groups from America (8\% in Chile and United States of America) and other continents (2-18\% in Asia, 0-14\% in Africa and 15\% in Europe) [21,59-64].

The HOMA-IR values were higher in the O-GDM group compared to the N-GDM group. While there are no cut-off values for HOMA-IR during pregnancy and only one report suggests that GDM is associated with HOMA-IR values over 2.6 during T1 [44], our findings suggest that, in GDM, obesity could be associated with increased insulin resistance, which is a concept widely recognized in nonpregnant populations [65-68].

It is well documented that newborns from women with GDM present macrosomia as a consequence of hyperinsulinemia [69,70]. However, macrosomia was absent in the offspring of this studied group. This phenomenon could be related to the normal glucose, insulin and TG levels observed at term in all women of the studied groups due to the assigned GDM treatments received during pregnancy [21,70-72].

Regarding the lipid profile, all of the studied groups showed increased TC, LDL and TG levels during pregnancy, as previously reported for the women in group C and women with GDM [15,16]. This physiological change is required to fulfill all of the needs of the developing fetus [25,30,73-82].

Nevertheless, a complex dyslipidemia state seems to be observed during pregnancy in the O-GDM group. Our results confirm the previous description of higher levels of TG and therefore of VLDL during T1 in the O-GDM group and during T2 in the N-GDM group [83-85]. The abnormal rise of TG in women with GDM is produced by high serum estrogen concentrations and augmented insulin resistance that generate hypertriglyceridemia [86]. Here, this result was evident in women from the O-GDM group from T1 and T2 who presented high HOMA-IR. While the literature broadly described women with GDM as being associated with increased TG levels during T3 [83,87-92], in this study, a normalization of this lipid level was observed, likely due to GDM treatments in both groups of women with GDM, which is in agreement with other reports [84].

Reports of low levels of HDL at T2 and T3 in women with GDM, especially in O-GDM, have been previously reported $[89,90,92-94]$. The reduction in HDL levels could likely be due to an exchange of TG for cholesterol ester in the core lipids of HDL [84]. We suggest that a decreased level of HDL is an important issue to consider since the cardio-protective functions of HDL could be impaired in these women [95]. 
Regarding LDL and in line with our results, some studies described reduced TC and LDL levels in obese women with GDM compared to $C$ women $[84,93,96]$. Other studies showed increased levels of TC in obese women with GDM with respect to $C$ women due to an increase in LDL [83,91]. In our O-GDM group, the reduced levels of TC and LDL were not related to maternal BMI (Table 2); thus, we propose that the changes are related to the chosen treatment for GDM (diet, metformin and/or insulin). Interestingly, inclusion of metformin for insulin-treated women with GDM was associated with reductions in TC and LDL during the last trimester of pregnancy, an effect that was not observed in insulin-treated patients.

Concerning GDM treatments, in this study, the most frequently used treatment was insulin in the N-GDM and O-GDM groups, in contrast to treatments used in other centers worldwide where the main treatment is diet $[43,97]$. Women in the O-GDM group received higher proportions of the three interventions to achieve proper glycemic levels, in comparison to women in the N-GDM group. The effect of different GDM treatments on the lipid profile was evaluated. It was found that TG, VLDL and HDL levels were comparable between the N-GDM and O-GDM groups under the different treatments. However, TC and LDL levels were differentially modulated by the different treatments. In the O-GDM group relative to the N-GDM group, TC and LDL were decreased in those treated with diet, increased in those treated with insulin and comparable in those who received all three treatments. In this regard, scarce information is known about the impact of GDM treatments on lipid regulation because these treatments are rarely measured as routine controls during pregnancy $[16,30]$. The decreased TC and LDL levels of women in the O-GDM group treated with diet could be due to changes in lipid metabolism, as described in obese patients with T2DM treated with diet [98]. The increase in plasma LDL levels produced by insulin therapy in women of the O-GDM group (Figure 3) has been previously reported in women with GDM [12,85]. However, the mechanisms associated with this change are largely unknown $[85,99]$. Since insulin resistance is higher in our O-GDM group compared to the N-GDM group, and since it has been shown that insulin resistance associates with increased cholesterol synthesis favoring the production of VLDL, and therefore its metabolization to LDL via the cholesteryl ester transfer protein (an enzyme whose activity increases during pregnancy) [100-102], we propose that cholesterol metabolism could be further altered in women of the O-GDM group who were treated with insulin. This phenomenon was not observed in women treated with insulin-sensitizing metformin (Figure 3), which could also decrease glycation levels present in LDL, as it occurs in patients with T2DM [103], thereby allowing normal binding between LDLs and their receptors and then decreasing LDL levels in plasma. While it is suggested that insulin therapy produces an improvement in lipid levels in women with GDM [37,38,93], other studies have also suggested that insulin therapy generates a pro-atherogenic profile in overweight and obese women with GDM, which is associated with increased levels of TC and TG, low levels of HDL and apo $\mathrm{AI}$ (the main protein of HDL), increased levels of the inflammatory marker interleukin-6 [12,14,85,99], impaired blood flow in the forearm skin [14,104] and greater arterial stiffness after delivery [105]. Therefore, in some women, insulin therapy could worsen the maternal cardiovascular profile [99].

It is widely recognized that GDM is associated with impaired endothelial-dependent relaxation of umbilical vein rings and feto-placental endothelial dysfunction [106]. Interestingly, these alterations are still present in the feto-placental vasculature from women with GDM and are treated with diet or insulin [11,22], suggesting that factors other than glucose may be involved in the pathophysiology of GDM. We propose that maternal TC levels could be one of the possible factors contributing to this phenomenon. In line with this hypothesis, our results showed reduced endothelial-dependent relaxation of umbilical vein rings from pregnant women with GDM with increased levels of TC (levels comparable to those described in the O-GDM group treated with diet plus insulin, Figure 3), in comparison to rings from women with GDM with normal TC levels. These results show, for first the time, that maternal TC levels have an impact on the feto-placental endothelial dysfunction associated with GDM, although the participating mechanisms remain unknown. We suggest that increased TC levels could worsen feto-placental endothelial function by modifying nitric oxide availability, which 
has been previously shown in rings from the placental vessels from pregnant women without GDM, but increased TC levels [23-25,27]. Therefore, we propose that increased levels of TC, as described in obese women with GDM treated with insulin, could impair feto-placental endothelial function.

In addition to the possible involvement of the nitric oxide signaling in this study, it would be interesting to evaluate the nitric oxide metabolites and the oxidative stress in these samples as well, since these pathways are affected in GDM and dyslipidemic pregnancies [54,107-109]. However, what is happening with these parameters when they are present at the same time is still unknown.

Finally, and regarding the use of CGRP in our experiments of vascular reactivity, even though CGRP is an unusual vasodilator in classical experiments in aortic or mesenteric vessels, in the human umbilical vessels (veins and arteries), which is a vascular bed that lacks innervation [26], it is used as an endothelium-dependent relaxant agent [110].

CGRP is an aminoacid neuropeptide [111] that acts through a seven transmembrane domain $\mathrm{G}$ protein-coupled receptor, calcitonin receptor-like receptor (CRLR), which has three ligands: adrenomedullin, intermedin and CGRP. In addition, three receptor activity modifying proteins: RAMP1, RAMP2, and RAMP3. Coexpression of CRLR with RAMP1 forms a CGRP receptor [112]. In the human placenta, both CRLR and RAMP1 are expressed in the endothelium and underlying smooth muscle cells in the umbilical, chorionic and stem villous vessels [110], suggesting that CGRP may play a role in the control of feto-placental vascular tone [113], and therefore is a physiologic vasodilator in these vascular beds. Actually, it has been shown that chronic administration of CGRP antagonist CGRP8-37 to pregnant rats caused a significant reduction in pup weight and increased systolic blood pressure and fetal mortality rate [114], and these effects were dose dependent, suggesting that CGRP may be involved in the control of feto-placental circulation [113].

Similar experiments were performed with Insulin as a vasodilator, but GDM endothelial response was impaired as we expected likely do to a dysregulation in the glucose metabolism (Supplementary Figure S2). Noticeable, when NTC- and HTC-C vascular reactivity was performed in placenta as well, but using Sodium nitroprusside (SNP) as a nitric oxide (NO) donor, no changes were observed between control groups with normal and high cholesterol levels, suggesting that the mechanisms independent of the NO machinery are intact (supplementary Figure S3).

\section{Conclusions}

In summary, our data suggest that GDM treatments differentially modulate TC levels in nonobese and obese pregnant women, which could be an important factor modulating feto-placental endothelial function. Therefore, we propose that TC modulation should be considered an additional target for GDM management strategies. Thus, GDM therapy selection should be performed according to the maternal nutritional state and lipid profile to avoid further potential impairment of the feto-placental endothelial function (Figure 5).

GDM treatments are focused in control glycemia and weight but not lipids, which are also dysregulated in these patients. In this study, all the schemes used to treat the disease succeed in the control of glycemia. However, lipid levels were not well controlled and this control was weight-dependent and lipid specific, i.e., TC and LDL were improved in O-GDM respect to N-GDM when these women were treated with Diet and the opposite effect was observed when these patients were treated with Diet + Insulin. Furthermore, it has been described that when glucose levels are controlled, but TC is elevated in N and N-GDM women, the feto-placental vasculature is impaired. Nevertheless, when glucose and TC are corrected, feto-placental vasculature could be improved. Abbreviations: GDM: Gestational Diabetes Mellitus; N: Nonobese; O: Obese; LDL: Low Density Lipoprotein; TC: Total Cholesterol; HTC: High Total Cholesterol; NTC: Normal Total Cholesterol Dashed lines correspond to our proposal. 

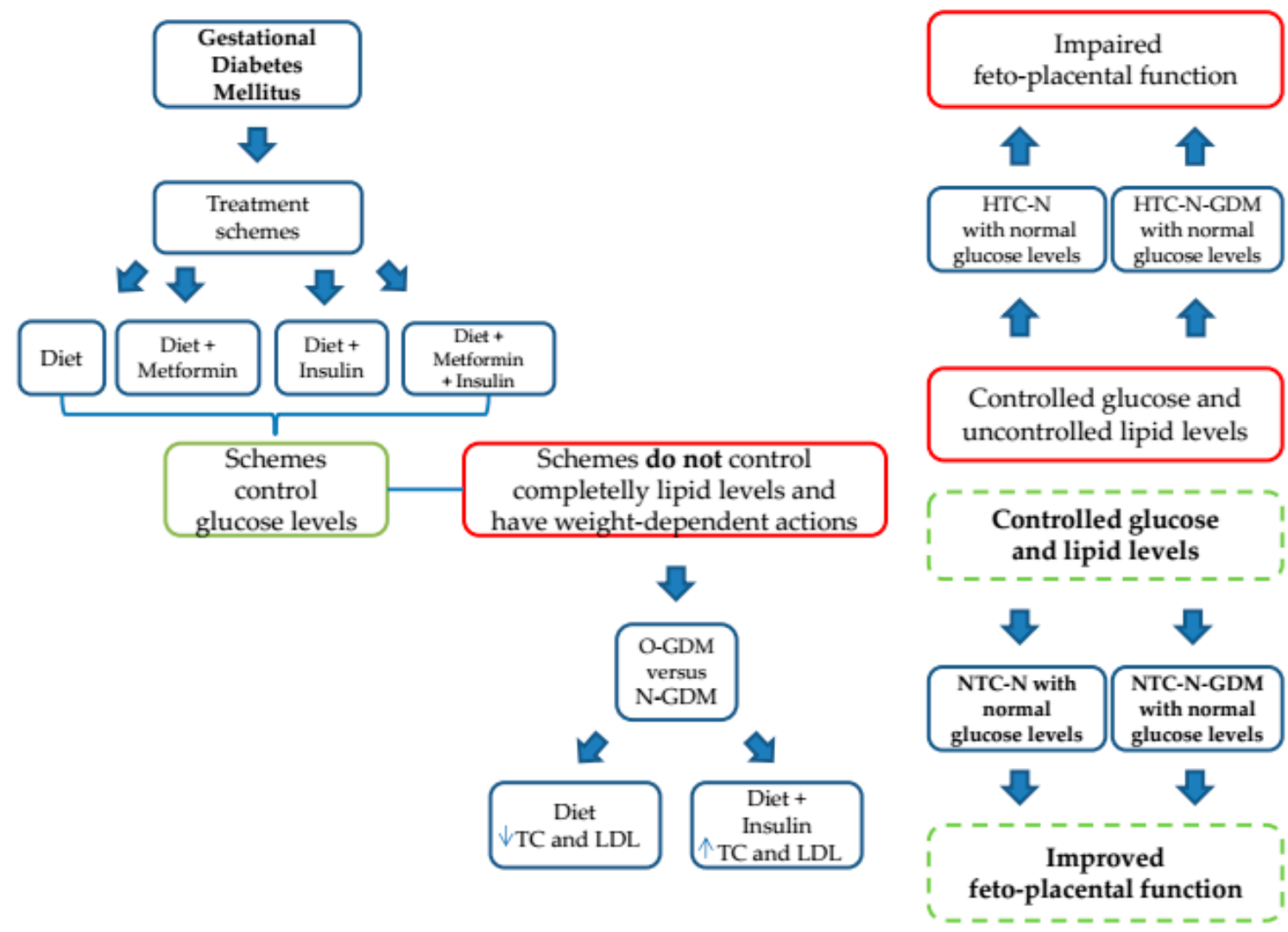

Figure 5. Schematic summary.

Supplementary Materials: The following are available online at http://www.mdpi.com/2072-6643/12/2/506/s1, Figure S1: Maximal relaxation endothelium-dependent of human umbilical vein rings from nonobese control and with gestational diabetes mellitus women in response to CGRP; Figure S2: Dilation of human umbilical vein rings endothelial-dependent from nonobese control women and women with gestational diabetes mellitus in response to Insulin; Figure S3: Dilation endothelial-independent of human umbilical vein rings from nonobese control women with normal and high cholesterol in response to Sodium nitroprusside (SNP).

Author Contributions: S.C.-D., M.J.G. and M.F. analyzed all the clinical data. L.C. and M.S. performed the experiments for vascular reactivity. S.C.-D., C.C. and B.F. prepared the figures and tables. S.C.-D. and A.L. designed the study. S.C.-D. and A.L. wrote and edited the manuscript. All authors reviewed the manuscript. All authors have read and agreed to the published version of the manuscript.

Acknowledgments: We would like to thank the staff at Hospital Clínico UC-Christus labor ward for supplying biological samples. We would also like to thank to Luis Villarroel for his statistical assistance and to the Cellular and Molecular Physiology Laboratory for allowing us to use their equipment. This work was supported by Fondo Nacional de Desarrollo Científico y Tecnológico (FONDECYT 3180442, 1190250). BF, CC and LC hold fellowships from the Comisión Nacional de Ciencia y Tecnología (CONICYT, Chile). BF and CC hold School of Medicine, PUC (Chile) fellowships.

Conflicts of Interest: The authors declare no competing interests.

\section{References}

1. American Diabetes Association. Classification and diagnosis of diabetes. Diabetes Care 2017, 40, S11-S24. [CrossRef]

2. World Health Organization. Diagnostic criteria and classification of hyperglycaemia first detected in pregnancy. Diabetes Res. Clin. Pract. 2013, 103, 341-363.

3. Metzger, B.; Lowe, L.; Dyer, A.; Trimble, E.; Chaovarindr, U.; Coustan, D.; Hadden, D.; McCance, D.; Hod, M.; McIntyre, H.; et al. Hyperglycemia and adverse pregnancy outcomes. HAPO Study Cooperative Research Group. N. Engl. J. Med. 2008, 358, 1991-2002. [PubMed] 
4. Kjos, S.; Buchanan, T. Gestational diabetes mellitus. N. Engl. J. Med. 1999, 341, 1749-1756. [CrossRef] [PubMed]

5. Chu, S.; Callaghan, W.; Kim, S.; Schmid, C.; Lau, J.; England, L.; Dietz, P. Maternal obesity and risk of gestational diabetes mellitus. Diabetes Care 2007, 30, 2070-2076. [CrossRef] [PubMed]

6. Kongubol, A.; Phupong, V. Prepregnancy obesity and the risk of gestational diabetes mellitus. BMC Pregnancy Childbirth 2011, 10, 59. [CrossRef] [PubMed]

7. Padmanabhan, S.; Wagstaff, A.; Tung, V.; Chan, Y.; Bartlett, A.; Lau, S.M. Increase in body mass index during pregnancy and risk of gestational diabetes. Diabetes Res. Clin. Pract. 2014, 106, e79-e82. [CrossRef]

8. Colomiere, M.; Permezel, M.; Riley, C.; Desoye, G.; Lappas, M. Defective insulin signaling in placenta from pregnancies complicated by gestational diabetes mellitus. Eur. J. Endocrinol. 2009, 160, 567-578. [CrossRef]

9. Guzmán-Gutiérrez, E.; Arroyo, P.; Salsoso, R.; Fuenzalida, B.; Sáez, T.; Leiva, A.; Pardo, F.; Sobrevia, L. Role of insulin and adenosine in the human placenta microvascular and macrovascular endothelial cell dysfunction in gestational diabetes mellitus. Microcirculation 2014, 21, 26-37. [CrossRef]

10. Haas, T. Shaping and remodeling of the fetoplacental circulation: Aspects of health and disease. Microcirculation 2014, 21, 1-3. [CrossRef]

11. Subiabre, M.; Silva, L.; Villalobos-Labra, R.; Toledo, F.; Paublo, M.; López, M.A.; Salsoso, R.; Pardo, F.; Leiva, A.; Sobrevia, L. Maternal insulin therapy does not restore foetoplacental endothelial dysfunction in gestational diabetes mellitus. Biochim. Biophys. Acta Mol. Basis Dis. 2017, 1863, 2987-2998. [CrossRef] [PubMed]

12. Bayraktar, F.; Akinci, B.; Celtik, A.; Tunali, S.; Genc, S.; Ozcan, M.A.; Secil, M.; Yesil, S. Insulin need in gestational diabetes is associated with a worse cardiovascular risk profile after pregnancy. Intern. Med. 2012, 51, 839-843. [CrossRef] [PubMed]

13. Savvidou, M.; Anderson, J.; Kaihura, C.; Nicolaides, K. Maternal arterial stiffness in pregnancies complicated by gestational and type 2 diabetes mellitus. Am. J. Obstet. Gynecol. 2010, 203, e1-e7. [CrossRef] [PubMed]

14. Mrizak, I.; Arfa, A.; Fekih, M.; Debbabi, H.; Bouslema, A.; Boumaiza, I.; Zaouali, M.; Khan, N.A.; Tabka, Z. Inflammation and impaired endothelium-dependant vasodilatation in non obese women with gestational diabetes mellitus: Preliminary results. Lipids Health Dis. 2013, 12, 93. [CrossRef]

15. Ryckman, K.; Spracklen, C.; Smith, C.; Robinson, J.; Saftlas, A. Maternal lipid levels during pregnancy and gestational diabetes: A systematic review and meta-analysis. BJOG 2015, 122, 643-651. [CrossRef]

16. Contreras-Duarte, S.; Carvajal, L.; Fuenzalida, B.; Cantin, C.; Sobrevia, L.; Leiva, A. Maternal Dyslipidaemia in Pregnancy with Gestational Diabetes Mellitus: Possible Impact on Foetoplacental Vascular Function and Lipoproteins in the Neonatal Circulation. Curr. Vasc. Pharmacol. 2019, 17, 52-71. [CrossRef]

17. Akinci, B.; Celtik, A.; Genc, S.; Yener, S.; Demir, T.; Secil, M.; Kebapcilar, L.; Yesil, S. Evaluation of postpartum carbohydrate intolerance and cardiovascular risk factors in women with gestational diabetes. Gynecol. Endocrinol. 2011, 27, 361-367. [CrossRef]

18. Metzger, B. Long-term outcomes in mothers diagnosed with gestational diabetes mellitus and their offspring. Clin. Obstet. Gynecol. 2007, 50, 972-979. [CrossRef]

19. Daly, B.; Toulis, K.; Thomas, N.; Gokhale, K.; Martin, J.; Webber, J.; Keerthy, D.; Jolly, K.; Saravanan, P.; Nirantharakumar, K. Increased risk of ischemic heart disease, hypertension, and type 2 diabetes in women with previous gestational diabetes mellitus, a target group in general practice for preventive interventions: A population-based cohort study. PLoS Med. 2018, 15, e1002488. [CrossRef]

20. McKenzie-Sampson, S.; Paradis, G.; Healy-Profitós, J.; St-Pierre, F.; Auger, N. Gestational diabetes and risk of cardiovascular disease up to 25 years after pregnancy: A retrospective cohort study. Acta Diabetol. 2018, 55, 315-322. [CrossRef]

21. Olmos, P.; Rigotti, A.; Busso, D.; Berkowitz, L.; Santos, J.; Borzone, G.; Poblete, J.; Vera, C.; Belmar, C.; Goldenberg, D.; et al. Maternal hypertriglyceridemia: A link between maternal overweight-obesity and macrosomia in gestational diabetes. Obesity 2014, 22, 2156-2163. [CrossRef] [PubMed]

22. Subiabre, M.; Silva, L.; Toledo, F.; Paublo, M.; López, M.; Boric, M.; Sobrevia, L. Insulin therapy and its consequences for the mother, foetus, and newborn in gestational diabetes mellitus. Biochim. Biophys. Acta Mol. Basis Dis. 2018, 1864, 2949-2956. [CrossRef] [PubMed] 
23. Leiva, A.; de Medina, C.; Salsoso, R.; Sáez, T.; San Martín, S.; Abarzúa, F.; Farías, M.; Guzmán-Gutiérrez, E.; Pardo, F.; Sobrevia, L. Maternal hypercholesterolemia in pregnancy associates with umbilical vein endothelial dysfunction: Role of endothelial nitric oxide synthase and arginase II. Arterioscler. Thromb. Vasc. Biol. 2013, 33, 2444-2453. [CrossRef] [PubMed]

24. Leiva, A.; Fuenzalida, B.; Westermeier, F.; Toledo, F.; Salomón, C.; Gutiérrez, J.; Sanhueza, C.; Pardo, F.; Sobrevia, L. Role for tetrahydrobiopterin in the fetoplacental endothelial dysfunction in maternal supraphysiological hypercholesterolemia. Oxid. Med. Cell. Longev. 2015, 2015, 5346327. [CrossRef] [PubMed]

25. Leiva, A.; Fuenzalida, B.; Salsoso, R.; Barros, E.; Toledo, F.; Gutiérrez, J.; Pardo, F.; Sobrevia, L. Tetrahydrobiopterin Role in human umbilical vein endothelial dysfunction in maternal supraphysiological hypercholesterolemia. Biochim. Biophys. Acta 2016, 1862, 536-544. [CrossRef]

26. Marzioni, D.; Tamagnone, L.; Capparuccia, L.; Marchini, C.; Amici, A.; Todros, T.; Bischof, P.; Neidhart, S.; Grenningloh, G.; Castellucci, M. Restricted innervation of uterus and placenta during pregnancy: Evidence for a role of the repelling signal Semaphorin 3A. Dev. Dyn. 2004, 231, 839-848. [CrossRef]

27. Fuenzalida, B.; Sobrevia, B.; Cantin, C.; Carvajal, L.; Salsoso, R.; Gutiérrez, J.; Contreras-Duarte, S.; Sobrevia, L.; Leiva, A. Maternal supraphysiological hypercholesterolemia associates with endothelial dysfunction of the placental microvasculature. Sci. Rep. 2018, 8, 7690. [CrossRef]

28. IOM. Weight Gain during Pregnancy: Reexamining the Guidelines; Institute of Medicine (us) and National research Council (us) and Committee To Reexamine iom Pregnancy Weight Guidelines; The National Academies Press: Cambridge, MA, USA, 2009.

29. Taskinen, M.; Borén, J. New insights into the pathophysiology of dyslipidemia in type 2 diabetes. Atherosclerosis 2015, 239, 483-495. [CrossRef]

30. Barrett, H.; Dekker Nitert, M.; McIntyre, H.; Callaway, L. Normalizing metabolism in diabetic pregnancy: Is it time to target lipids? Diabetes Care 2014, 37, 1484-1493. [CrossRef]

31. Rhodes, E.; Pawlak, D.; Takoudes, T.; Ebbeling, C.; Feldman, H.; Lovesky, M.; Cooke, E.; Leidig, M.; Ludwig, D. Effects of a low-glycemic load diet in overweight and obese pregnant women: A pilot randomized controlled trial. Am. J. Clinl. Nutr. 2010, 92, 1306-1315. [CrossRef]

32. Wang, H.; Jiang, H.; Yang, L.; Zhang, M. Impacts of dietary fat changes on pregnant women with gestational diabetes mellitus: A randomized controlled study. Asia. Pac. J. Clin. Nutr. 2015, 24, 58-64. [PubMed]

33. Asemi, Z.; Samimi, M.; Tabassi, Z.; Sabihi, S.; Esmaillzadeh, A. A randomized controlled clinical trial investigating the effect of DASH diet on insulin resistance, inflammation, and oxidative stress in gestational diabetes. Nutrition 2013, 29, 619-624. [CrossRef] [PubMed]

34. Asemi, Z.; Tabassi, Z.; Samimi, M.; Fahiminejad, T.; Esmaillzadeh, A. Favourable effects of the dietary approaches to stop hypertension diet on glucose tolerance and lipid profiles in gestational diabetes: A randomised clinical trial. Br. J. Nutr. 2013, 109, 2024-2030. [CrossRef] [PubMed]

35. Jamilian, M.; Asemi, Z. The effect of soy intake on metabolic profiles of women with gestational diabetes mellitus. J. Clin. Endocrinol. Metab. 2015, 100, 4654-4661. [CrossRef]

36. Magee, M.; Knopp, R.; Benedetti, T. Metabolic effects of 1200-kcal diet in obese pregnant women with gestational diabetes. Diabetes 1990, 39, 234-240. [CrossRef]

37. Barrett, H.; Dekker Nitert, M.; Jones, L.; O’Rourke, P.; Lust, K.; Gatford, K.; De Blasio, M.; Coat, S.; Owens, J.; Hague, W.; et al. Determinants of maternal triglycerides in women with gestational diabetes mellitus in the Metformin in Gestational Diabetes (MiG) study. Diabetes Care 2013, 36, 1941-1946. [CrossRef]

38. Barrett, H.; Gatford, K.; Houda, C.; De Blasio, M.; McIntyre, H.; Callaway, L.; Dekker Nitert, M.; Coat, S.; Owens, J.; Hague, W.; et al. Maternal and neonatal circulating markers of metabolic and cardiovascular risk in the metforminin gestational diabetes $(\mathrm{MiG})$ trial: Responses to maternal metformin versus insulin treatment. Diabetes Care 2013, 36, 529-536. [CrossRef]

39. Zawiejska, A.; Wender-Ozegowska, E.; Grewling-Szmit, K.; Brazert, M.; Brazert, J. Short-term antidiabetic treatment with insulin or metformin has a similar impact on the components of metabolic syndrome in women with gestational diabetes mellitus requiring antidiabetic agents: Results of a prospective, randomised study. J. Physiol. Pharmacol. 2016, 67, 227-233.

40. Krishnamoorthy, U.; Schram, C.; Hill, S. Maternal obesity in pregnancy: Is it time for meaningful research to inform preventive and management strategies? BJOG 2006, 113, 1134-1140. [CrossRef] 
41. American College of Obstetricians and Gynecologists. Task Force on Hypertension in Pregnancy. Obstet. Gynecol. 2013, 122, 1122-1131.

42. American Diabetes Association. Standars of medical care in diabetes. Diabetes Care 2013, 36, S11-S66.

43. American Diabetes Association. Standards of Medical Care in Diabetes Summary of Revisions. Diabetes Care 2015, 38, S4. [CrossRef] [PubMed]

44. Schnell, Z.; Leeuwen, A.; Kranpitz, T. Davis's Comprehensive Laboratory and Diagnostic Test Handbook-with Nursing Implications, 2nd ed.; F.A. Davis Company: Philadelphia, PA, USA, 2006; pp. 1-1804.

45. Ozcimen, E.; Uckuyu, A.; Ciftci, F.; Yanik, F.; Bakar, C. Diagnosis of gestational diabetes mellitus by use of the homeostasis model assessment-insulin resistance index in the first trimester. Gynecol. Endocrinol. 2008, 24, 224-229. [CrossRef] [PubMed]

46. Matthews, D.; Hosker, J.; Rudenski, A.; Naylor, B.; Treacher, D.; Turner, R. Homeostasis model assessment: Insulin resistance and beta-cell function from fasting plasma glucose and insulin concentrations in man. Diabetologia 1985, 28, 412-419. [CrossRef] [PubMed]

47. Buccini, G.; Wolfthal, D. Valores de corte para índices de insulinorresistencia, inmunosensibilidad e insulinosecreción derivados de la fórmula HOMA y del programa HOMA2. Interpretación de los datos. RAEM 2008, 45, 3-21.

48. Wallace, T.; Levy, J.; Matthews, D. Use and Abuse of HOMA Modeling. Diabetes Care 2004, 27, 61487-61495. [CrossRef]

49. National Institute for Health and Clinical Excellence. Diabetes in Pregnancy: Management of Diabetes and Its Complications from Preconception to the Postnatal Period; RCOG Press: London, UK, 2008.

50. Ministerio de salud. Guía Perinatal, Gobierno de Chile 2015; Ministerio de salud: Santiago, Chile, 2015; pp. 1-466.

51. Olmos, P.; Borzone, G. Basal-bolus insulin therapy reduces maternal triglycerides in gestational diabetes without modifying cholesteryl ester transfer protein activity. Obstet. Gynaecol. Res. 2017, 43, 1397-1404. [CrossRef]

52. Napoli, C.; D’Armiento, F.; Mancini, F.; Postiglione, A.; Witztum, J.; Palumbo, G.; Palinski, W. Fatty streak formation occurs in human fetal aortas and is greatly enhanced by maternal hypercholesterolemia. Intimal accumulation of low density lipoprotein and its oxidation precede monocyte recruitment into early atherosclerotic lesions. Clin. Investig. 1997, 100, 2680-2690. [CrossRef]

53. Napoli, C.; Glass, C.; Witztum, J.; Deutsch, R.; D’Armiento, F.; Palinski, W. Influence of maternal hypercholesterolaemia during pregnancy on progression of early atherosclerotic lesions in childhood: Fate of Early Lesions in Children (FELIC) study. Lancet 1999, 354, 1234-1241. [CrossRef]

54. Liguori, A.; D'Armiento, F.; Palagiano, A.; Balestrieri, M.; Williams-Ignarro, S.; de Nigris, F.; Lerman, L.; D'Amora, M.; Rienzo, M.; Fiorito, C.; et al. Effect of gestational hypercholesterolaemia on omental vasoreactivity, placental enzyme activity and transplacental passage of normal and oxidised fatty acids. BJOG 2007, 114, 1547-1556. [CrossRef]

55. Marseille-Tremblay, C.; Ethier-Chiasson, M.; Forest, J.; Giguère, Y.; Masse, A.; Mounier, C.; Lafond, J. Impact of maternal circulating cholesterol and gestational diabetes mellitus on lipid metabolism in human term placenta. Mol. Reprod. Dev. 2008, 75, 1054-1062. [CrossRef]

56. Zhang, R.; Dong, S.; Ma, W.; Cai, X.; Le, Z.; Xiao, R.; Zhou, Q.; Yu, H. Modulation of cholesterol transport by maternal hypercholesterolemia in human full-term placenta. PLoS ONE 2017, 12, e0171934. [CrossRef] [PubMed]

57. Knopp, R.; Magee, M.; Raisys, V.; Benedetti, T.; Bonet, B. Hypocaloric diets and ketogenesis in the management of obese gestational diabetic women. J. Am. Coll Nutr. 1991, 10, 649-667. [CrossRef]

58. Metzger, B.; Freinkel, N. Accelerated starvation in pregnancy: Implications for dietary treatment of obesity and gestational diabetes mellitus. Biol. Neonate 1987, 51, 78-85. [CrossRef] [PubMed]

59. Belmar, C.; Salinas, P.; Becker, J.; Abarzua, F.; Olmos, P.; Gonzalez, P.; Oyarzun, E. Incidence of gestational diabetes according to two diagnostic criteria and its clinical impact. Rev. Chil. Obstet. Gynecol. 2004, 69, $2-7$.

60. Zhou, T.; Sun, D.; Li, X.; Heianza, Y.; Nisa, H.; Hu, G.; Pei, X.; Shang, X.; Qi, L. Prevalence and trends in gestational diabetes mellitus among women in the united states, 2006-2016. Diabetes 2018, 67, S1. [CrossRef]

61. Hirst, J.; Raynes-Greenow, C.; Jeffery, H. A systematic review of trends of gestational diabetes mellitus in Asia. J. Diabetol. 2012, 3, 5. 
62. Nguyen, C.; Pham, N.; Binns, C.; Duong, D.; Lee, A. Prevalence of gestational diabetes mellitus in eastern and southeastern asia: A systematic review and meta-analysis. J. Diabetes Res. 2018, 20, 6536974. [CrossRef]

63. Macaulay, S.; Dunger, D.; Norris, S. Gestational diabetes mellitus in Africa: A systematic review. PLoS ONE 2014, 9, e97871. [CrossRef]

64. Melchior, H.; Kurch-Bek, D.; Mund, M. The Prevalence of Gestational Diabetes. Dtsch. Arztebl. Int. 2017, 114, 412-418.

65. Després, J. The insulin resistancedyslipidemic syndrome of visceral obesity: Effect on patients' risk. Obes. Res. 1998, 6, 8S-17S. [CrossRef] [PubMed]

66. Kahn, B.; Flier, J. Obesity and insulin resistance. J. Clin. Investig. 2000, 106, 473-481. [CrossRef] [PubMed]

67. Ye, J. Mechanisms of insulin resistance in obesity. Front. Med. 2013, 7, 14-24. [CrossRef]

68. Hardy, O.; Czech, M.; Corvera, S. What causes the insulin resistance underlying obesity? Curr. Opin. Endocrinol. Diabetes Obes. 2012, 19, 81-87. [CrossRef]

69. Kc, K.; Shakya, S.; Zhang, H. Gestational diabetes mellitus and macrosomia: A literature review. Ann. Nutr. Metab. 2015, 66, 14-20. [CrossRef]

70. Plows, J.; Stanley, J.; Baker, P.; Reynolds, C.; Vickers, M. The pathophysiology of gestational diabetes mellitus. Int. J. Mol. Sci. 2018, 19, 3342. [CrossRef]

71. Schwartz, R.; Gruppuso, P.; Petzold, K.; Brambilla, D.; Hiilesmaa, V.; Teramo, K. Hyperinsulinemia and macrosomia in the fetus of the diabetic mother. Diabetes Care 1994, 17, 640-648. [CrossRef]

72. Ryan, D.; Haddow, L.; Ramaesh, A.; Kelly, R.; Johns, E.; Denison, F.; Dover, A.; Reynolds, R. Early screening and treatment of gestational diabetes in high-risk women improves maternal and neonatal outcomes: A retrospective clinical audit. Diabetes Res. Clin. Pract. 2018, 144, 294-301. [CrossRef]

73. Desoye, G.; Schweditsch, M.; Pfeiffer, K.; Zechner, R.; Kostner, G. Correlation of hormones with lipid and lipoprotein levels during normal pregnancy and postpartum. J. Clin. Endocrinol. Metab. 1987, 64, 704-712. [CrossRef]

74. Herrera, E.; Amusquivar, E.; López-Soldado, I.; Ortega, H. Maternal lipid metabolism and placental lipid transfer. Horm. Res. 2006, 65, 59-64. [CrossRef]

75. Herrera, E.; Desoye, G. Maternal and fetal lipid metabolism under normal and gestational diabetic conditions. Horm. Mol. Biol. Clin. Investig. 2016, 26, 109-127. [CrossRef] [PubMed]

76. Knopp, R.; Warth, M.; Charles, D.; Childs, M.; Li, J.; Mabuchi, H.; Van Allen, M. Lipoprotein metabolism in pregnancy, fat transport to the fetus, and the effects of diabetes. Biol. Neonate 1986, 50, 297-317. [CrossRef] [PubMed]

77. Geraghty, A.; Alberdi, G.; O’Sullivan, E.; O’Brien, E.; Crosbie, B.; Twomey, P.; McAuliffe, F. Maternal and fetal blood lipid concentrations during pregnancy differ by maternal body mass index: Findings from the ROLO study. BMC Pregnancy Childbirth 2017, 17, 360. [CrossRef]

78. Lippi, G.; Albiero, A.; Montagnana, M.; Salvagno, G.; Scevarolli, S.; Franchi, M.; Guidi, G. Lipid and lipoprotein profile in physiological pregnancy. Clin. Lab. 2007, 53, 173-177.

79. Warth, M.; Knopp, R. Lipid metabolism in pregnancy. V. Interactions of diabetes, body weight, age, and high carbohydrate diet. Diabetes 1977, 26, 1056-1062. [CrossRef]

80. Emet, T.; Ustüner, I.; Güven, S.; Balık, G.; Ural, U.; Tekin, Y.; Sentürk, S.; Sahin, F.; Avşar, A. Plasma lipids and lipoproteins during pregnancy and related pregnancy outcomes. Arch. Gynecol. Obstet. 2013, 288, 49-55. [CrossRef]

81. Jin, W.; Lin, S.; Hou, R.; Chen, X.; Han, T.; Jin, Y.; Tang, L.; Zhu, Z.; Zhao, Z. Associations between maternal lipid profile and pregnancy complications and perinatal outcomes: A population-based study from China. BMC Pregnancy Childbirth 2016, 21, 60. [CrossRef]

82. Wiznitzer, A.; Mayer, A.; Novack, V.; Sheiner, E.; Gilutz, H.; Malhotra, A.; Novack, L. Association of lipid levels during gestation with preeclampsia and gestational diabetes mellitus: A population-based study. Am. J. Obstet. Gynecol. 2009, 201, e1-e8. [CrossRef]

83. Sánchez-Vera, I.; Bonet, B.; Viana, M.; Quintanar, A.; Martín, M.; Blanco, P.; Donnay, S.; Albi, M. Changes in plasma lipids and increased low-density lipoprotein susceptibility to oxidation in pregnancies complicated by gestational diabetes: Consequences of obesity. Metabolism 2007, 56, 1527-1533. [CrossRef]

84. Hollingsworth, D.; Grundy, S. Pregnancy-associated hypertriglyceridemia in normal and diabetic women. Differences in insulin-dependent, non-insulin-dependent, and gestational diabetes. Diabetes 1982, 31, 1092-1097. [CrossRef] 
85. Kern Pessôa, V.; Rodacki, M.; Negrato, C.; Zajdenverg, L. Changes in lipid profile after treatment of women with gestational diabetes mellitus. J. Clin. Lipidol. 2016, 10, 350-355. [CrossRef] [PubMed]

86. Metzger, B.; Phelps, R.; Freinkel, N.; Navickas, I. Effects of gestational diabetes on diurnal profiles of plasma glucose, lipids, and individual amino acids. Diabetes Care 1980, 3, 402-409. [CrossRef] [PubMed]

87. Wang, D.; Xu, S.; Chen, H.; Zhong, L.; Wang, Z. The associations between triglyceride to high-density lipoprotein cholesterol ratios and the risks of gestational diabetes mellitus and large-for-gestational-age infant. Clin. Endocrinol. 2015, 83, 490-497. [CrossRef] [PubMed]

88. Whyte, K.; Kelly, H.; O’Dwyer, V.; Gibbs, M.; O'Higgins, A.; Turner, M. Offspring birth weight and maternal fasting lipids in women screened for gestational diabetes mellitus (GDM). Eur. J. Obstet. Gynecol. Reprod. Biol. 2013, 170, 67-70. [CrossRef]

89. Zhou, J.; Zhao, X.; Wang, Z.; Hu, Y. Combination of lipids and uric acid in mid-second trimester can be used to predict adverse pregnancy outcomes. Matern. Fetal. Neonatal. Med. 2012, 25, 2633-2638. [CrossRef]

90. Maple-Brown, L.; Ye, C.; Hanley, A.; Connelly, P.; Sermer, M.; Zinman, B.; Retnakaran, R. Maternal pregravid weight is the primary determinant of serum leptin and its metabolic associations in pregnancy, irrespective of gestational glucose tolerance status. J. Clin. Endocrinol. Metab. 2012, 97, 4148-4155. [CrossRef]

91. Giannubilo, S.; Tiano, L.; Cecchi, S.; Principi, F.; Tranquilli, A.; Littarru, G. Plasma coenzyme Q10 is increased during gestational diabetes. Diabetes Res. Clin. Pract. 2011, 94, 230-235. [CrossRef]

92. Qiu, C.; Rudra, C.; Austin, M.; Williams, M. Association of gestational diabetes mellitus and low-density lipoprotein (LDL) particle size. Physiol. Res. 2007, 56, 571-578.

93. Dubé, E.; Ethier-Chiasson, M.; Lafond, J. Modulation of cholesterol transport by insulin-treated gestational diabetes mellitus in human full-term placenta. Biol. Reprod. 2013, 88, 16. [CrossRef]

94. Ghafoor, S.; Shaikh, A. Shaheena. Maternal lipids in pregnancies with gestational diabetes mellitus. Pak. J. Med. Health. Sci. 2012, 6, 81-84.

95. Sreckovic, I.; Birner-Gruenberger, R.; Besenboeck, C.; Miljkovic, M.; Stojakovic, T.; Scharnagl, H.; Marsche, G.; Lang, U.; Kotur-Stevuljevic, J.; Jelic-Ivanovic, Z.; et al. Gestational diabetes mellitus modulates neonatal high-density lipoprotein composition and its functional heterogeneity. Biochim. Biophys. Acta 2014, 1841, 1619-1627. [CrossRef]

96. Koukkou, E.; Watts, G.; Lowy, C. Serum lipid, lipoprotein and apolipoprotein changes in gestational diabetes mellitus: A cross-sectional and prospective study. J. Clin. Pathol. 1996, 49, 634-637. [CrossRef] [PubMed]

97. Magon, N.; Seshiah, V. Gestational diabetes mellitus: Insulinic management. J. Obstet. Gynaecol. India 2014, 64, 82-90. [CrossRef] [PubMed]

98. Wang, Y.; Snel, M.; Jonker, J.; Hammer, S.; Lamb, H.; de Roos, A.; Meinders, A.; Pijl, H.; Romijn, J.; Smit, J.; et al. Prolonged caloric restriction in obese patients with type 2 diabetes mellitus decreases plasma CETP and increases apolipoprotein AI levels without improving the cholesterol efflux properties of HDL. Diabetes Care 2011, 34, 2576-2580. [CrossRef] [PubMed]

99. Retnakaran, R.; Qi, Y.; Connelly, P.; Sermer, M.; Hanley, A.; Zinman, B. The graded relationship between glucose tolerance status in pregnancy and postpartum levels of low-density-lipoprotein cholesterol and apolipoprotein B in young women: Implications for future cardiovascular risk. Clin. Endocrinol. Metab. 2010, 95, 4345-4353. [CrossRef]

100. Herrera, E.; Ortega-Senovilla, H. Disturbances in lipid metabolism in diabetic pregnancy-Are these the cause of the problem? Best Pract. Res. Clin. Endocrinol. Metab. 2010, 24, 515-525. [CrossRef]

101. Pihlajamäki, J.; Gylling, H.; Miettinen, T.A.; Laakso, M. Insulin resistance is associated with increased cholesterol synthesis and decreased cholesterol absorption in normoglycemic men. J. Lipid. Res. 2004, 45, 507-512. [CrossRef]

102. Hoenig, M.; Sellke, F. Insulin resistance is associated with increased cholesterol synthesis, decreased cholesterol absorption and enhanced lipid response to statin therapy. Atherosclerosis 2010, 211, 260-265. [CrossRef]

103. Rabbani, N.; Chittari, M.; Bodmer, C.; Zehnder, D.; Ceriello, A.; Thornalley, P. Increased glycation and oxidative damage to apolipoprotein B100 of LDL cholesterol in patients with type 2 diabetes and effect of metformin. Diabetes 2010, 59, 1038-1045. [CrossRef]

104. Hannemann, M.; Liddell, W.; Shore, A.; Clark, P.; Tooke, J. Vascular function in women with previous gestational diabetes mellitus. J. Vasc. Res. 2002, 39, 311-319. [CrossRef] 
105. Kärkkäinen, H.; Laitinen, T.; Heiskanen, N.; Saarelainen, H.; Valtonen, P.; Lyyra-Laitinen, T.; Vanninen, E.; Heinonen, S. Need for insulin to control gestational diabetes is reflected in the ambulatory arterial stiffness index. BMC Pregnancy Childbirth 2013, 16, 9. [CrossRef] [PubMed]

106. Westermeier, F.; Salomón, C.; González, M.; Puebla, C.; Guzmán-Gutiérrez, E.; Cifuentes, F.; Leiva, A.; Casanello, P.; Sobrevia, L. Insulin restores gestational diabetes mellitus-reduced adenosine transport involving differential expression of insulin receptor isoforms in human umbilical vein endothelium. Diabetes 2011, 60, 1677-1687. [CrossRef] [PubMed]

107. Lappas, M.; Hiden, U.; Desoye, G.; Froehlich, J.; Hauguel-de Mouzon, S.; Jawerbaum, A. The role of oxidative stress in the pathophysiology of gestational diabetes mellitus. Antioxid. Redox Signal. 2011, 15, 3061-3100. [CrossRef] [PubMed]

108. Chen, X.; Scholl, T.O. Oxidative stress: Changes in pregnancy and with gestational diabetes mellitus. Curr. Diab. Rep. 2005, 5, 282-288. [CrossRef]

109. Sun, Y.; Kopp, S.; Strutz, J.; Gali, C.C.; Zandl-Lang, M.; Fanaee-Danesh, E.; Kirsch, A.; Cvitic, S.; Frank, S.; Saffery, R.; et al. Gestational diabetes mellitus modulates cholesterol homeostasis in human fetoplacental endothelium. Biochim. Biophys. Acta Mol. Cell Biol. Lipids 2018, 1863, 968-979. [CrossRef]

110. Dong, Y.L.; Vegiraju, S.; Gangula, P.R.; Yallampalli, C. Involvement of CGRP in control of human fetoplacental vascular tone. Am. J. Physiol. Heart Circ. Physiol. 2004, 286, H230-H239. [CrossRef]

111. Rosenfeld, M.G.; Mermod, J.J.; Amara, S.G.; Swanson, L.W.; Swchenko, P.E.; Rivier, J.; Vale, W.W.; Evans, R.M. Production of a novel neuropeptide encoded by the calcitonin gene via tissue-specific RNA processing. Nature 1983, 304, 129-135. [CrossRef]

112. Roh, J.; Chang, C.L.; Bhalla, A.; Klein, C.; Hsu, S.Y.T. Intermedin is a calcitonin/ calcitonin gene-related peptide family peptide acting through the calcitonin receptor-like receptor/receptor activity-modifying protein receptor complexes. J. Biol. Chem. 2004, 279, 7264-7274. [CrossRef]

113. Dong, Y.L.; Green, K.E.; Vegiragu, S.; Hankins, G.D.; Martin, E.; Chauhan, M.; Thota, C.; Yallampalli, C. Evidence for Decreased Calcitonin Gene-Related Peptide (CGRP) Receptors and Compromised Responsiveness to CGRP of Fetoplacental Vessels in Preeclamptic Pregnancies. J. Clin. Endocrinol. Metab. 2005, 90, 2336-2343. [CrossRef]

114. Gangula, P.R.R.; Dong, Y.L.; Wimalawansa, S.J.; Yallampalli, C. Infusion of pregnant rats with calcitonin gene-related peptide (CGRP)(8-37), a CGRP receptor antagonist, increases blood pressure and fetal mortality and decreases fetal growth. Biol. Reprod. 2002, 67, 624-629. [CrossRef] 